\title{
Microwave Assisted Synthesis and Antimicrobial Potential of Quinoline-Based 4- Hydrazide-Hydrazone Derivatives
}

\author{
Olayinka O. Ajani, ${ }^{\text {a,* }}$ King T. Iyaye, ${ }^{\text {a }}$ Oluwatosin Y. Audu, ${ }^{\mathrm{b}}$ Shade J. Olorunshola, ${ }^{\mathrm{c}}$ Alice \\ O. Kuye ${ }^{\mathrm{c}}$ and Ifedolapo O. Olanrewaju ${ }^{\mathrm{a}}$
}

${ }^{a}$ Department of Chemistry, Covenant University, CST, Canaanland, Km 10 Idiroko Road,

P.M.B. 1023, Ota, Ogun State, Nigeria.

${ }^{b}$ Department of Chemistry, University of Pretoria, Private Bag X20, Hatfield 0028, South Africa.

'Department of Biological Sciences, Covenant University, CST, Canaanland, Km 10 Idiroko

Road, P.M.B. 1023, Ota, Ogun State, Nigeria.

*E-mail: ola.ajani@ covenantuniversity.edu.ng; Tel.: +234-806-167-0254.

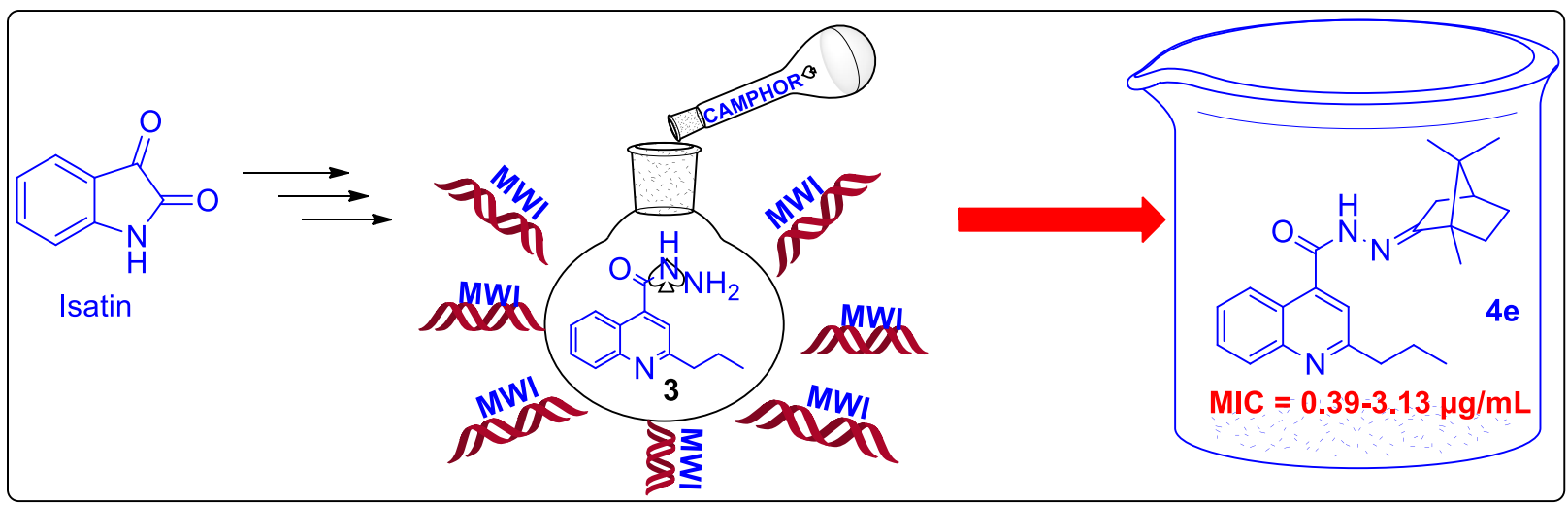

\begin{abstract}
Quinoline is a benzo-fused pyridine which is a therapeutically important heterocycle in medicinal chemistry research and new drug development. A series of 12 new hydrazide-hydrazone motifs bearing quinoline core $\mathbf{4 a - 1}$ was successfully synthesized by microwave irradiation technique. The synthesis involved four steps strategies which was initiated by ring-opening synthetic modification of isatin to quinoline-4-carboxylic acid through Pfitzinger approach. The structure of the reactive intermediates 1, $\mathbf{2}$ and $\mathbf{3}$ as well as the targeted quinoline 4a-l were confirmed by the result of physico-chemical parameters and spectroscopic means which include FT-IR, UV, ${ }^{1} \mathrm{H}$ and ${ }^{13} \mathrm{C}$ NMR as well as DEPT 135 NMR. The in vitro antimicrobial screening of the targeted hydrazidehydrazones 4a-l alongside with gentamicin (clinical standard) against six microorganisms was determined using agar diffusion. The result from the MIC test showed that this series of hydrazidehydrazones exhibited remarkable efficacy as antimicrobial agents with $\mathbf{4 e}$ being the most active antibacterial agent with MIC value ranging from 3.13 to $0.39 \mu \mathrm{g} / \mathrm{mL}$ on the six organisms tested.
\end{abstract}


Key words: Pfitzinger synthesis; hydrazide; quinoline core; spectral study; antibacterial agent

\section{INTRODUCTION}

The structure of un-substituted quinoline was confirmed by the syntheses in which allylaniline was passed over glowing lead oxide or from $o$-nitrocinnamaldehyde [1]. Quinoline is characterized by a double ring structure composed of benzene and pyridine ring fused at two adjacent carbon atoms, while the pyridine ring contains five carbon atoms and a nitrogen heteroatom [2]. Due to wide application of quinoline core in many medicinal and industrial processes, various synthetic approaches have been used for the synthesis of this valuable heterocyclic system. These methods include: Pfitzinger approach which is reaction of isatin with ketones and aldehyde [3]; Doebner-Von Miller method, which comprises of reaction of an aniline with $\alpha, \beta$-unsaturated carbonyl compounds [4]; Conrad-Limpach method which is based on the condensation of anilines with $\beta$-ketoesters [5]; Combe synthetic approach which involves the reaction of $\beta$-diketones, with primary aryl amines like aniline [6] and Friedlander synthetic approach which proceeded by the condensation of 2 -aminoaryl ketones with $\alpha$-methyleneketones [7]. Another method which has become one of the most efficient processes for the synthesis of quinolines is Povarov synthetic approach which is an inverse electron demand aza-Diels-Alder reaction of $N$-aryl imines, derived from aldehydes and anilines, with electron rich olefins [8] and Skraup method [9]. Quinoline skeletons are recurrently encountered heterocyclic compounds in medicinal chemistry literature with wide spread pharmacological diversity such as anticancer [10] antioxidant [11], antileishmanial [12], antibacterial [13], analgesic, anti-inflammatory [14], antifungal [15], antimalarial [16], antitumor [17] and DNA enzyme topoisomerase I inhibitory [18] among others.

Furthermore, in the recent time, the chemistry of carbon-nitrogen double bond of hydrazone is fast becoming the backbone of condensation reaction in benzo-fused $N$-heterocycles [19]. Hydrazone containing azomethine $-\mathrm{NHN}=\mathrm{CH}$ protons constitute an important class of compounds for new drug development [19] which have been reported to possess, among others, antimicrobial [20], antitubercular [21], and antiplatelet [22]. Also, a recent review on pharmacological activities of hydrazone derivatives showed them to display anticonvulsant, antiinflammatory, antimalarial, antioxidant, antidepressant and antifungal [23]. In an earlier review, which dealt with exploring biological activities of hydrazone, it was unveiled that they exhibited analgesic, central nervous system (CSN), antiprotozoal, cardio-protective and anticancer activities [24]. Due to occurrence of microorganisms' drug resistance and emergence of new diseases which have contributed to the alarming rate of global health threat, there is a continuous need for the synthesis of new heterocyclic compounds as potential antimicrobial agents. Therefore, we have herein designed and synthesized twelve novel hydrazide-hydrazones of quinoline $\mathbf{4 a - 1}$ in order to investigate their antimicrobial potential for possible future drug discovery.

\section{RESULTS AND DISCUSSION}

Chemistry: In the continuation of our research effort on the design and discovery of biologically active hydrazones $[19,20]$, we have herein embarked upon the microwave-assisted synthesis of quinoline-based hydrazide-hydrazone through an eco-friendly synthetic approach in order to evaluation their antimicrobial potentials for possible future drug discovery. First and foremost, the reaction was initiated by the synthesis of 2-propylquinoline-4-carboxylic acid (1) 
according to the Pfitzinger synthetic procedure earlier reported [3]. This involved the ring-opening reaction of isatin under the influence of aqueous $\mathrm{KOH}$ by heating under reflux, followed by ketonization of the reactive intermediate with pentan-2-one at a reflux temperature of $80-90{ }^{\circ} \mathrm{C}$ for $13 \mathrm{~h}$ to form the potassium salt of 2-propylquinoline-4-carboxylic acid. The choice of pentanone as the required ketone is to access 2-propyl substitution on the quinoline nucleus. The resulting solution was then worked-up by acidification with concentrated hydrochloric acid $(\mathrm{Conc}$. $\mathrm{HCl})$ to a $\mathrm{pH}$ of 2 , after which colored solid was precipitated. It was cooled and the solid formed was filtered by suction and air-dried to afford 2-propylquinoline-4-carboxylic acid $\mathbf{1}$ as red colored crystalline compound (Scheme 1). Secondly, the compound (1) was esterified via reaction with absolute ethanol at temperature of $60^{\circ} \mathrm{C}$ by heating under reflux for $1 \mathrm{~h}$ in the presence of catalytic amount of concentrated sulphuric acid $\left(\mathrm{Conc} . \mathrm{H}_{2} \mathrm{SO}_{4}\right)$ to achieve a solution which was worked-up by adding water and extracted in two portions with diethyl ether. The organic layer was combined and dried over anhydrous $\mathrm{Na}_{2} \mathrm{SO}_{4}$ to trap any escaped moisture. The filtrate was evaporated to dryness in order to afford ethyl 2-propylquinoline-4-carboxylate, 2 (Scheme 2a). Subsequently, the hydrazinolysis of $\mathbf{2}$ was carried out by reacting it under reflux for $1 \mathrm{~h}$ with equimolar quantity of hydrazine hydrate in ethanolic environment to afford 2-propylquinoline-4-carbohydrazide, 3 in high yield (Scheme $2 b$ ). Finally, new twelve derivatives of hydrazide-hydrazone bearing quinoline core, 4a-l were synthesized by microwave assisted condensation reaction of the $\mathrm{NH}_{2}$ free end of hydrazide of intermediate 3 with $\mathrm{sp}^{2}$ hybridized carbonyl center of various aliphatic and alicyclic ketones in the presence of ethanol (Scheme 3). The microwave assisted reaction was completed between 1 and $3 \mathrm{~min}$. The thermodynamic justification for faster reaction rate under microwave was explained in our previous work [20].

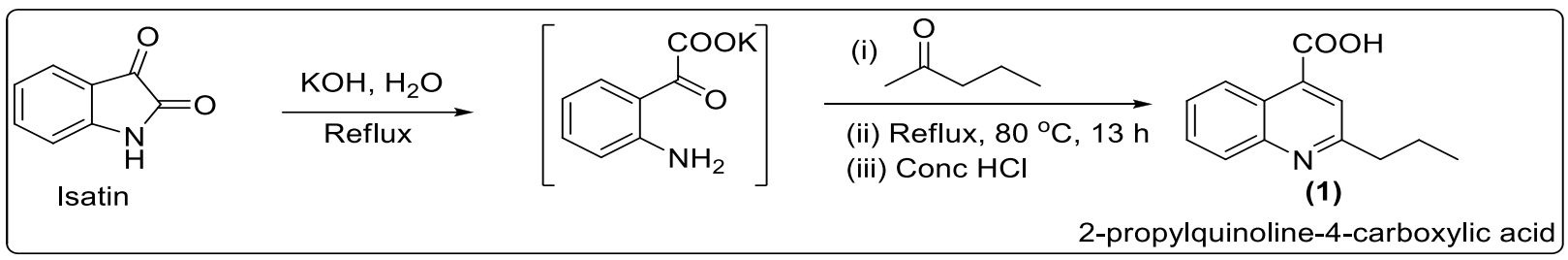

Scheme 1. Pathway for the synthesis of 2-propylquinoline-4-carboxylic acid, 1.

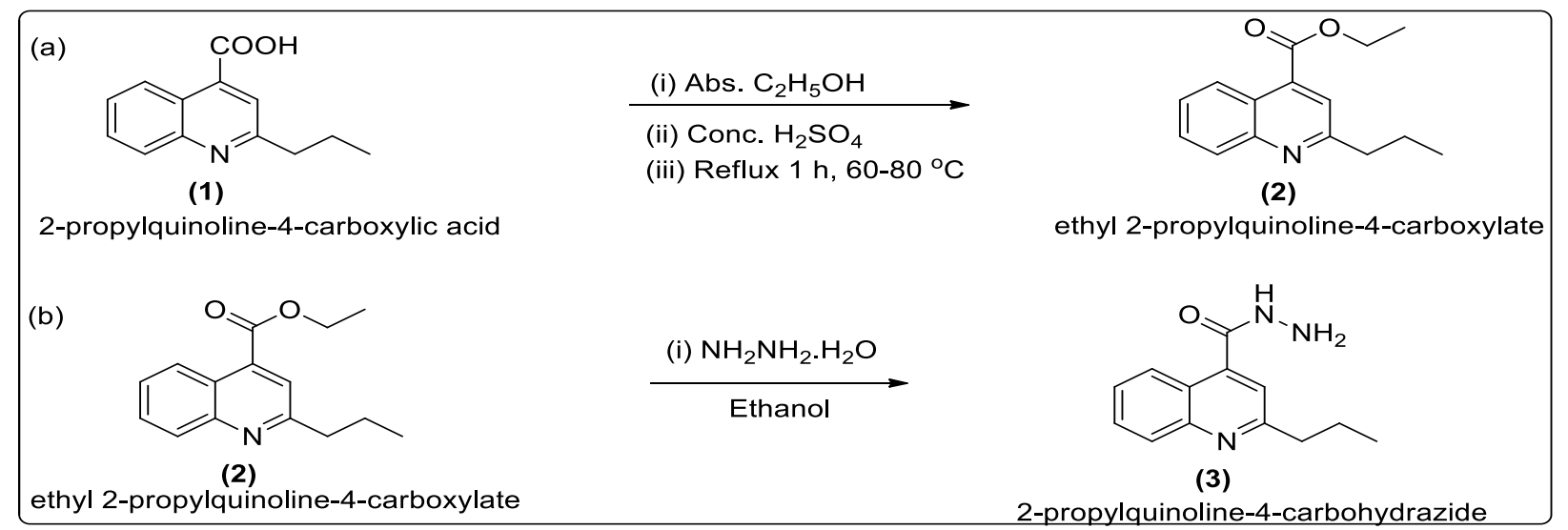

Scheme 2. Pathways for the synthesis of (a) ethyl 2-propylquinoline-4-carboxylate, 2. (b) and quinoline hydrazide, 2-propylquinoline-4-carbohydrazide, $\mathbf{3}$. 
Characterization: Spectroscopic characterization of the newly synthesized hydrazidehydrazones 4a-l was carried out using uv-visible, IR spectral data, ${ }^{1} \mathrm{H}$ NMR, ${ }^{13} \mathrm{C}$ NMR and DEPT 135. According to the spectroscopic study, the electronic transition of uv-visible spectra for the hydrazide-hydrazones of quinoline, 4a-l gave rise to wavelength $\left(\lambda_{\max }\right)$ ranging from $203 \mathrm{~nm}$ for $\mathbf{4 a}$ to $428 \mathrm{~nm}$ for $\mathbf{4 l}$ with $\log \varepsilon_{\max }$ of 4.04 for both (Experimental). The first set of wavelengths $\left(\lambda_{\max }\right)$ in all the synthesized compounds were found between $203-225 \mathrm{~nm}$ and they were as a result of $л \rightarrow \Omega^{*}$ transition indicating the presence of $C=C$ peculiar to benzene nucleus. This indicated that all the hydrazide-hydrazones, $4 \mathbf{a}-\mathbf{l}$ possessed benzene ring as one of their core system. Considering $4 \mathbf{a}$ as a representative of the targeted compounds, its first wavelength was $203 \mathrm{~nm}\left(\log \varepsilon_{\max }=4.04\right)$ while some bathochromic shifts were experienced at $225 \mathrm{~nm}\left(\log \varepsilon_{\max }=4.08\right), 251 \mathrm{~nm}\left(\log \varepsilon_{\max }=\right.$ 4.10), $254 \mathrm{~nm}\left(\log \varepsilon_{\max }=4.38\right)$ and $305 \mathrm{~nm}\left(\log \varepsilon_{\max }=4.11\right)$. They were as a result of the combinatory effect of $\pi \rightarrow n$ transition of $\mathrm{C}=\mathrm{O}$ and $\mathrm{C}=\mathrm{N}$ as well as extensive conjugation of $\mathrm{C}=\mathrm{C}$ moieties. The longest wavelength of $428 \mathrm{~nm}\left(\log \varepsilon_{\max }=4.04\right)$ was observed in compound 4l. This might be due to the presence of auxochromic character of $\mathrm{C}=\mathrm{N}$ and additional $\mathrm{C}=\mathrm{C}$ conjugation contributed by the benzene of the coumarin template. The infrared spectra of all the compounds, 4a-l showed absorption bands due to the stretching vibration of $\mathrm{N}-\mathrm{H}$ of hydrazide, $\mathrm{C}-\mathrm{H}$ of aromatic, $\mathrm{C}-\mathrm{H}$ of aliphatic, $\mathrm{C}=\mathrm{O}$ of hydrazide and amide, $\mathrm{C}=\mathrm{C}$ of aromatic and $\mathrm{C}=\mathrm{N}$ of hydrazone and imine at $3415-3244 \mathrm{~cm}^{-1}, 3151-3010 \mathrm{~cm}^{-1}, 2981-2804 \mathrm{~cm}^{-1}, 1715-1668 \mathrm{~cm}^{-1}, 1638-1603 \mathrm{~cm}^{-1}$ and $1589-1575 \mathrm{~cm}^{-1}$ respectively. The absorption bands observed at bending vibrational frequencies of $1467-1360 \mathrm{~cm}^{-1}, 1254-1123 \mathrm{~cm}^{-1}, 987-965 \mathrm{~cm}^{-1}$, and $774-722 \mathrm{~cm}^{-1}$ depicted the presence of aliphatic $\left(\mathrm{CH}_{3}, \mathrm{CH}_{2}\right)$ deformation, $\mathrm{C}-\mathrm{N}$ of hydrazide, $=\mathrm{C}-\mathrm{H}$ bending and aryl bonded hydrogen respectively. In addition, some bands were peculiar to some compounds alone and not for the entire targeted scaffolds. In terms of the ranges of the bands of each functional group, the highest N-H band was found in $\mathbf{4 a}, \mathbf{4 e}, \mathbf{4 f}, \mathbf{4 h}$ at $3415 \mathrm{~cm}^{-1}$ while the lowest $\mathrm{N}-\mathrm{H}$ band was found in $\mathbf{4 d}$ at $3244 \mathrm{~cm}^{-1}$. The $\mathrm{C}-\mathrm{H}$ band of aromatic ranged from $3151 \mathrm{~cm}^{-1}$ for $\mathbf{4 b}$ to $3010 \mathrm{~cm}^{-1}$ for $\mathbf{4 g}$ and $\mathbf{4 h}$. Carbonyl bands were available for all the compounds with carbonyl of amide in $\mathbf{4 g}$ being the highest $\left(1715 \mathrm{~cm}^{-1}\right)$ while the carbonyl of hydrazide of $\mathbf{4 c}$ had the lowest carbonyl absorption frequency of $1668 \mathrm{~cm}^{-1}$. In a similar manner, the stretching vibrational frequency of $\mathrm{C}=\mathrm{C}$ varied between $1638 \mathrm{~cm}^{-1}$ for compound $(\mathbf{4 c})$ to $1603 \mathrm{~cm}^{-1}$ for compound $\mathbf{4 b}$ while the highest absorption frequency for $\mathrm{C}=\mathrm{N}$ was $1589 \mathrm{~cm}^{-1}$ for $\mathbf{4 b}, \mathbf{4 k}$ and lowest being $1575 \mathrm{~cm}^{-1}$ for $\mathbf{4 i}, \mathbf{4 j}, \mathbf{4 k}$. The deformed aliphatic groups attached to benzene were found between $1467 \mathrm{~cm}^{-1}$ for $\mathbf{4 b}, \mathbf{4 k}$ to 1360 $\mathrm{cm}^{-1}$ for $4 \mathbf{i}$. The confirmatory evidence for the $\mathrm{C}-\mathrm{N}$ of hydrazide was responsible for the bands ranging from $1254 \mathrm{~cm}^{-1}$ for $\mathbf{4 f}$ to $1123 \mathrm{~cm}^{-1}$ for $\mathbf{4 c}$ while the rest of the bands were at the finger print region.

Furthermore, the physico-chemical parameters of the synthesized compounds 4a-l evaluated and documented were molecular formula, molecular weight, percentage yields, melting points, colour and elemental composition values for carbon, hydrogen and oxygen (Experimental). The molecular weight of the compounds, 4a-l ranged from 283.87 for $\mathbf{4 a}$ to 399.44 for $\mathbf{4 1}$. The weights were above $200 \mathrm{~g} / \mathrm{mol}$, which partially revealed the bicyclic nature of the compounds, 4al, since a monocyclic aromatic has molecular weight $<200 \mathrm{~g} / \mathrm{mol}$ (e.g. benzene $=78 \mathrm{~g} / \mathrm{mol}$ ). The majority of the compounds have arbitrarily high melting point values and $\mathbf{4 e}, \mathbf{4 f}, \mathbf{4 l}$ did not even melt at $300{ }^{\circ} \mathrm{C}$. It is a clear indication of the formation of hydrazide bond which has similar thermal behaviour as amide bond with high tendency of hydrogen bonding character. This was in agreement with our earlier finding [19] wherein 3-hydrazinoquinoxalin-2(1H)-one was reported to have high melting point values (M.p. > $360{ }^{\circ} \mathrm{C}$ ). The percentage yields of the synthesized hydrazide-hydrazones $\mathbf{4 a - l}$ ranged from $70 \%$ for $\mathbf{4 d}$ to $94 \%$ for $\mathbf{4 l}$. The good to excellent yields 
obtained showed that microwave irradiation technique was cost-effective and highly efficient in the complete conversion of the precursor to the quinoline-based hydrazide-hydrazones, $\mathbf{4 a - 1}$. The visual observation of the compounds showed that the color varied in the order: red for $\mathbf{4 f}$; yellow for 4l; white for $\mathbf{4 e}$; black for $\mathbf{4 h}$ and $\mathbf{4 k}$, while the rest of the compounds were brown. The result of elemental analysis did not only correlate well with the molecular masses of the compounds but also showed a consistent minimum difference of not more than \pm 0.24 between $\%$ calculated and $\%$ found for the carbon, hydrogen and nitrogen of the prepared compounds, 4a-l (Experimental).

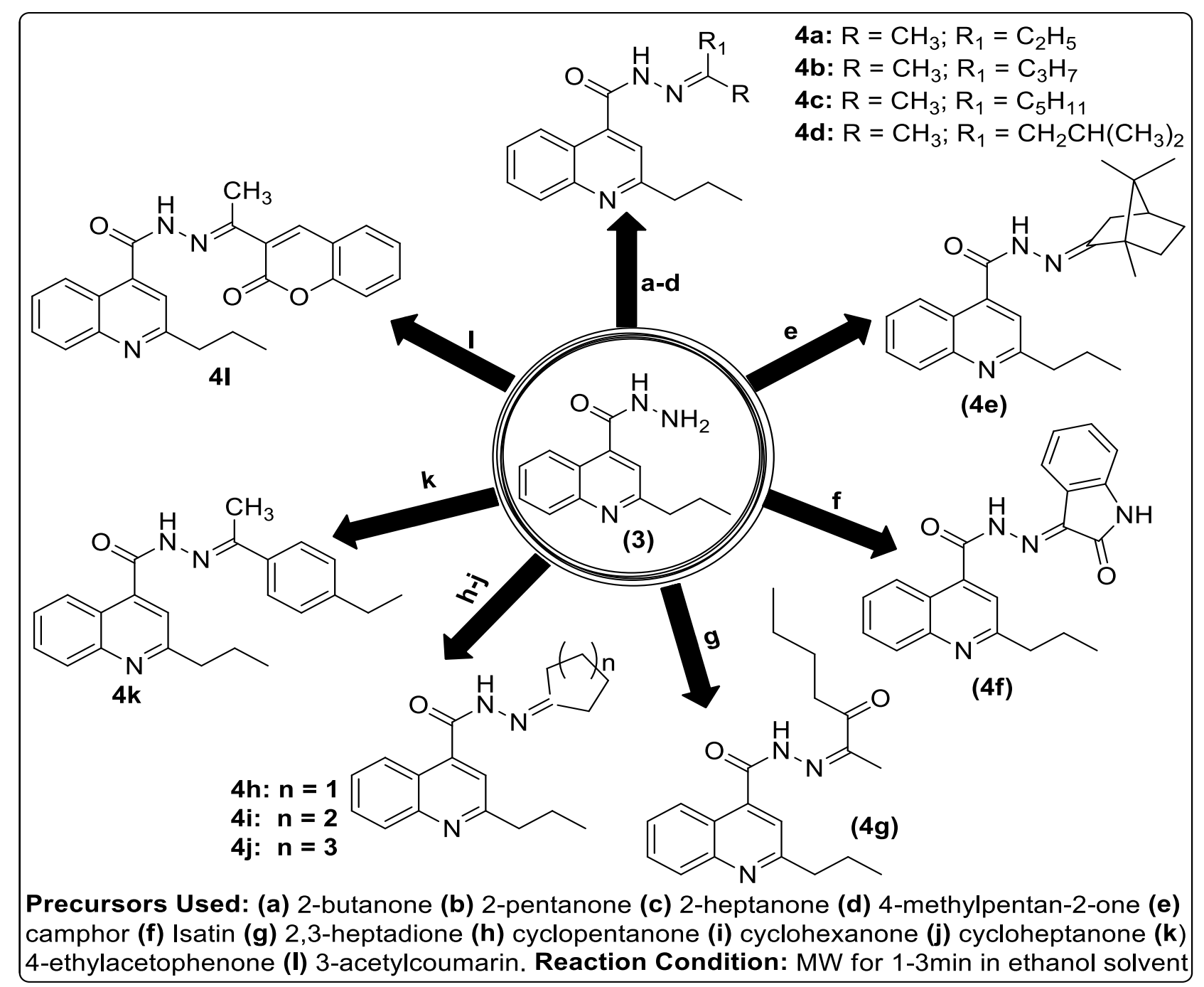

Scheme 3. Hydrazide-hydrazones of quinoline core, 4a-l.

Antimicrobial activity: Antimicrobial sensitivity testing of targeted hydrazide-hydrazones 4a-I was carried out in vitro against six organisms using agar-well diffusion method [25]. The media were inoculated with test organisms and DMSO was used as negative control. The positive control on bacteria was gentamicin. The zones of inhibition (Z.O.I.) in millimetres were measured after $24 \mathrm{~h}$ of incubation and duly recorded as shown in Table 1. The choice of gentamicin as clinical standard is because, at low concentrations, gentamicin only inhibits growth of the bacteria through 
induction of prokaryotic ribosomes to misread mRNA [19]. Gentamicin also prevents initiation of protein synthesis and leads to death of microbial cells. Gentamicin inhibits bacterial growth by inhibiting protein biosynthesis just like Streptomycin and other aminoglycoside antibiotics. Interestingly, it was observed that majority of the compounds exhibited probable and highly promising significant activities based on the large zone of inhibition reported. In fact, many of these hydrazide-hydrazone of quinoline derivatives 4a-l had larger zones of inhibition against all the six organisms when compared with gentamicin standard. Generally speaking, compound $\mathbf{4 h}$ showed the largest zone of inhibition ( $42.00 \pm 1.25 \mathrm{~mm}$ ) against $S$. aureus while $\mathbf{4 g}$ had the least zone of inhibition of $3.00 \pm 0.45 \mathrm{~mm}$ against $E$. coli among all the screened compounds.

The compound 4a-l inhibited the growth of $S$. aureus effectively with Z.O.I. ranging from 18.00 $\pm 1.11 \mathrm{~mm}$ for $\mathbf{4 c}$ to $42.00 \pm 1.25 \mathrm{~mm}$ for $\mathbf{4 h}$ while Z.O.I. of gentamicin against the same organism was $23.00 \pm 1.25 \mathrm{~mm}$. Thus, compounds $\mathbf{4 k}$ competed favourably with gentamicin while all other compounds showed better activity than gentamicin with larger zones of inhibition (i.e. Z.O.I. > 23 $\mathrm{mm}$ ) except compounds $\mathbf{4 c}$ and $\mathbf{4 g}$ with Z.O.I. of $18 \pm 1.11 \mathrm{~mm}$ and $19 \pm 1.20 \mathrm{~mm}$ respectively against $S$. aureus. The antimicrobial activity against Bacillus lichenformis showed that $\mathbf{4 a}$ had largest Z.O.I. of $38.00 \pm 1.25 \mathrm{~mm}$ while the least growth inhibitor was $\mathbf{4 g}$ with Z.O.I. of $8.00 \pm$ $1.00 \mathrm{~mm}$. The Z.O.I. of gentamicin against B. lichenformis was $15.00 \pm 1.08 \mathrm{~mm}$. This helped us to know that four compounds, $\mathbf{4 d}, \mathbf{4 g}, \mathbf{4 h}, \mathbf{4 i}$ had Z.O.I. values which were lower than that of gentamicin while the remaining eight compounds inhibited the growth of $B$. lichenformis at Z.O.I. value larger than that of gentamicin. With respect to Micrococcus varians, compounds $4 \mathbf{a}$ and $\mathbf{4 e}$ were the most probable growth inhibitors due to their large Z.O.I. value of $33.00 \pm 1.25 \mathrm{~mm}$ while $\mathbf{4 g}$ was the least probable due to small Z.O.I. value of $8.00 \pm 1.00 \mathrm{~mm}$. The Z.O.I. of gentamicin against $M$. varians was $18.00 \pm 1.21 \mathrm{~mm}$. This assisted in identifying that there were five compounds having Z.O.I. values $(20.00 \pm 1.17 \mathrm{~mm}$ to $33.00 \pm 1.25 \mathrm{~mm})$ greater than that of clinical standard (gentamicin) while seven compounds were having Z.O.I. values ( $8.00 \pm 1.00 \mathrm{~mm}$ to 14.00 $\pm 1.14 \mathrm{~mm}$ ) less than that of gentamicin as far as growth inhibitory potential against $M$. varians was concerned.

Nevertheless, upon the screening against three gram negative organisms (E. coli, $P$. vulgaris, $P$. aeruginosa), noticeable activities were observed, except screening of 4 a against $P$. vulgaris and gentamicin against $P$. aeruginosa where resistance was observed. According to screening against gram negative $E$. coli, the largest and smallest Z.O.I. were observed to be 30.00 $\pm 1.15 \mathrm{~mm}$ for $\mathbf{4 a} \& \mathbf{4 e}$ and $3.00 \pm 0.45 \mathrm{~mm}$ for $\mathbf{4 g}$ respectively. The Z.O.I. of gentamicin against E. coli was $25.00 \pm 1.19 \mathrm{~mm}$, which implied that $\mathbf{4 c}$ competed favourably with gentamicin while two compounds $\mathbf{4 a}$, 4e, inhibited $E$. coli growth at Z.O.I. larger than that of gentamicin. The antimicrobial activity against gram positive Proteus vulgaris depicted $\mathbf{4 g}$ as the most effective with largest Z.O.I. of $32.00 \pm 1.25 \mathrm{~mm}$ while $4 \mathbf{i}$ was the least active with smallest Z.O.I. of $8.00 \pm 0.44$ $\mathrm{mm}$. The in vitro screening of the samples $\mathbf{4 a - l}$ against Pseudomonas aeruginosa showed that all compounds were probably more active than gentamicin, since this organism ( $P$. aeruginosa) developed resistance against gentamicin, but had broad spectrum of activity with Z.O.I. ranging from $4.00 \pm 0.46 \mathrm{~mm}$ for $\mathbf{4 g}$ to $38.00 \pm 1.25 \mathrm{~mm}$ for $\mathbf{4 e}$. In the overall, hydrazide-hydrazone $\mathbf{4 e}$ had the best activity across the strains of the gram negative and gram positive organisms used in this present study.

\section{Table 1.}

The sensitivity testing of hydrazide-hydrazones $\mathbf{4 a - l}$ with zone of inhibition (mm) 


\begin{tabular}{lllllll}
\hline Sample & \multicolumn{5}{c}{ Organisms used and Z.O.I. (mm) } \\
Code & S. aureus & B. lichenformis & M. varians & E. coli & P. vulgaris & P. aeruginosa \\
\hline $\mathbf{4 a}$ & $39.00 \pm 1.25$ & $38.00 \pm 1.25$ & $33.00 \pm 1.25$ & $30.00 \pm 1.15$ & $\mathrm{R}$ & $29.00 \pm 1.10$ \\
$\mathbf{4 b}$ & $28.00 \pm 1.25$ & $23.00 \pm 1.04$ & $23.00 \pm 1.00$ & $15.00 \pm 1.01$ & $13.00 \pm 1.00$ & $24.00 \pm 1.11$ \\
$\mathbf{4 c}$ & $18.00 \pm 1.11$ & $31.00 \pm 1.25$ & $24.00 \pm 1.08$ & $25.00 \pm 1.25$ & $18.00 \pm 1.08$ & $26.00 \pm 1.09$ \\
$\mathbf{4 d}$ & $38.00 \pm 1.25$ & $13.00 \pm 1.00$ & $14.00 \pm 1.07$ & $11.00 \pm 1.01$ & $13.00 \pm 1.08$ & $20.00 \pm 1.14$ \\
$\mathbf{4 e}$ & $40.00 \pm 1.25$ & $33.00 \pm 1.25$ & $33.00 \pm 1.25$ & $30.00 \pm 1.15$ & $31.00 \pm 1.25$ & $38.00 \pm 1.25$ \\
$\mathbf{4 f}$ & $25.00 \pm 1.06$ & $16.00 \pm 1.00$ & $11.00 \pm 1.01$ & $15.00 \pm 1.08$ & $14.00 \pm 1.18$ & $14.00 \pm 1.14$ \\
$\mathbf{4 g}$ & $19.00 \pm 1.20$ & $8.00 \pm 1.00$ & $8.00 \pm 1.00$ & $3.00 \pm 0.45$ & $32.00 \pm 1.25$ & $4.00 \pm 0.46$ \\
$\mathbf{4 h}$ & $42.00 \pm 1.25$ & $11.00 \pm 1.00$ & $14.00 \pm 1.00$ & $4.00 \pm 0.39$ & $17.00 \pm 1.11$ & $8.00 \pm 0.39$ \\
$\mathbf{4 i}$ & $26.00 \pm 1.19$ & $13.00 \pm 1.03$ & $13.00 \pm 1.01$ & $13.00 \pm 1.03$ & $8.00 \pm 0.44$ & $8.00 \pm 0.41$ \\
$\mathbf{4 j}$ & $31.00 \pm 1.25$ & $24.00 \pm 1.21$ & $14.00 \pm 1.14$ & $18.00 \pm 1.22$ & $18.00 \pm 1.22$ & $25.00 \pm 1.25$ \\
$\mathbf{4 k}$ & $30.00 \pm 1.25$ & $16.00 \pm 1.14$ & $14.00 \pm 1.09$ & $19.00 \pm 1.21$ & $12.00 \pm 1.03$ & $22.00 \pm 1.25$ \\
$\mathbf{4 l}$ & $32.00 \pm 1.25$ & $25.00 \pm 1.24$ & $20.00 \pm 1.17$ & $15.00 \pm 1.07$ & $18.00 \pm 1.20$ & $20.00 \pm 1.25$ \\
$\mathbf{G e n t}$. & $23.00 \pm 1.25$ & $15.00 \pm 1.08$ & $18.00 \pm 1.21$ & $25.00 \pm 1.19$ & $25.00 \pm 1.20$ & $\mathrm{R}$
\end{tabular}

S. aureus = Staphylococcus aureus; B. lichenformis = Bacillus lichenformis; $M$. varians = Micrococcus varians; E. coli $=$ Escherichia coli $;$ P. vulgaris $=$ Proteus vulgaris $;$ P. aeruginosa $=$ Pseudomonas aeruginosa $;$ Gent. $=$ Gentamicin (Clinical standard); Z.O.I. $=$ Zone of Inhibition. Values are mean \pm SD of triplicate determination.

Both community-associated and hospital-acquired infections with Staphylococcus aureus have increased in the past 20 years. Types and presentation of $S$. aureus infection include the following: skin and soft tissue (impetigo) infection, scalded skin syndrome (Ritter disease), folliculitis, furuncle, bone infections (osteomyelitis) in children [26], septic arthritis, toxic shock syndrome, thrombophlebitis, deep tissue abscess and infection among other which in turn leads to high mortality rate [27]. Based on all the information aforementioned on S. aureus, the selectivity index (S.I.) of quinoline hydrazide-hydrazones 4a-l against the S. aureus was evaluated (Figure 1). The comparative study of activity potential of $\mathbf{4 a - 1}$ with gentamicin was considered since, in humans, gentamicin has structurally different ribosomes from bacteria, thereby allowing the selectivity of this antibiotic for bacteria. The selectivity index of gentamicin was unity, while any compounds with S.I. > 1, have a better selectivity index as compared with gentamicin whereas those with the S.I. $<1$ possessed lesser selectivity index than gentamicin antibiotic. On this note, it is interesting to note that four compounds $\mathbf{4 a}, \mathbf{4 d}, \mathbf{4 e}, \mathbf{4 h}$ exhibited a better selectivity index when compared with gentamicin against $S$. aureus, while the rest of the compounds were less selective than gentamicin on S. aureus. 


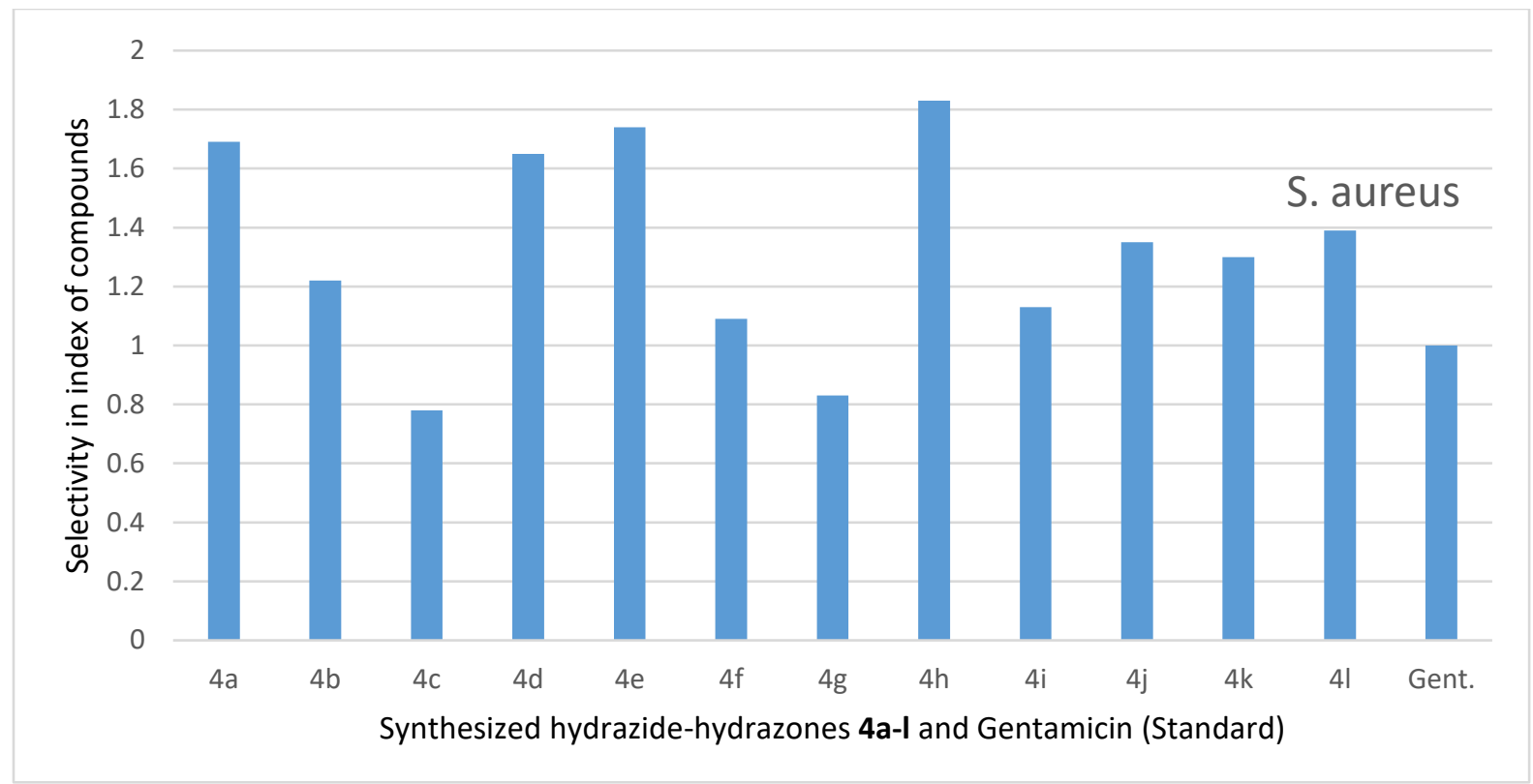

Figure 1. Result of the selectivity index of hydrazide-hydrazones (4a-1) against S. aureus.

Table 2.

The minimum inhibitory concentration (MIC) test of hydrazide-hydrazones $4 \mathbf{a}-\mathbf{l}(\mu \mathrm{g} / \mathrm{mL})$

\begin{tabular}{lcccccc}
\hline Code & \multicolumn{5}{c}{ Organism Used } \\
\cline { 2 - 7 } No & S. aureus & $\begin{array}{c}\text { B. } \\
\text { lichenformis }\end{array}$ & M. varians & E. coli & P. vulgaris & P. aeruginosa \\
\hline $\mathbf{4 a}$ & 0.39 & 6.25 & 6.25 & 25.00 & Nil & 12.50 \\
$\mathbf{4 b}$ & 0.39 & 25.00 & 1.56 & 12.50 & 6.25 & 25.00 \\
$\mathbf{4 c}$ & 0.39 & 1.56 & 6.25 & 0.78 & 6.25 & 1.56 \\
$\mathbf{4 d}$ & 0.39 & 6.25 & 3.13 & 3.13 & 1.56 & 6.25 \\
$\mathbf{4 e}$ & 1.56 & 1.56 & 3.13 & 3.13 & 0.39 & 0.78 \\
$\mathbf{4 f}$ & 0.39 & 1.56 & 3.13 & 6.25 & 12.50 & 1.56 \\
$\mathbf{4 g}$ & 0.39 & 3.13 & 3.13 & 12.50 & 6.25 & 3.13 \\
$\mathbf{4 h}$ & 0.39 & 12.50 & 12.50 & 25.00 & 25.00 & 50.00 \\
$\mathbf{4 i}$ & 0.39 & 3.13 & 3.13 & 3.13 & 6.25 & 3.13 \\
$\mathbf{4 j}$ & 0.78 & 12.50 & 3.13 & 6.25 & 3.13 & 12.50 \\
$\mathbf{4 k}$ & 0.39 & 6.25 & 3.13 & 1.56 & 12.50 & 25.00 \\
$\mathbf{4 l}$ & 0.39 & 1.56 & 3.13 & 25.00 & 6.25 & 3.13 \\
\hline & & & & & & \\
\hline
\end{tabular}


Based on the broad activity spectrum noticed during the antibacterial screening, MIC of the targeted compounds 4a-l was carried out against the six organisms using serial dilution method [25], with varying concentration from $50 \mu \mathrm{g} / \mathrm{mL}$ to $0.39 \mu \mathrm{g} / \mathrm{mL}$ as shown in Table 2 . The most susceptible organism to the efficacy of 4a-l was Staphylococcus aureus because thirteen compounds inhibited the growth of this organism at MIC value as low as $0.39 \mu \mathrm{g} / \mathrm{mL}$ except two compounds; $\mathbf{4 j}$ which inhibited S. aureus growth at MIC value of $0.78 \mu \mathrm{g} / \mathrm{mL}$ and $\mathbf{4 e}$ with MIC of $1.56 \mu \mathrm{g} / \mathrm{mL}$ against $S$. aureus growth. Thus, hydrazide-hydrazones, 4a-l synthesized herein could pave way for new drug development for combating infectious diseases caused by $S$. aureus. Compound 4a could not inhibit the growth of $P$. vulgaris at MIC value $\leq 50 \mu \mathrm{g} / \mathrm{mL}$. The MIC of synthesized compounds $4 a-l$ ranged from $1.56 \mu \mathrm{g} / \mathrm{mL}$ to $25.00 \mu \mathrm{g} / \mathrm{mL}$ against $B$. lichenformis; $1.56 \mu \mathrm{g} / \mathrm{mL}$ to $12.50 \mu \mathrm{g} / \mathrm{mL}$ against $M$. varians; $0.78 \mu \mathrm{g} / \mathrm{mL}$ to $25.00 \mu \mathrm{g} / \mathrm{mL}$ against $E$. coli; 0.39 $\mu \mathrm{g} / \mathrm{mL}$ to $25.00 \mu \mathrm{g} / \mathrm{mL}$ against $P$. vulgaris; $0.78 \mu \mathrm{g} / \mathrm{mL}$ to $50.00 \mu \mathrm{g} / \mathrm{ml}$ against $P$. aeruginosa. Based on the result of visual screening of MIC values across the gram positive and gram negative organisms used herein, compound $\mathbf{4 e}$ emerged as the most potent antimicrobial agent with MIC from $0.39 \mu \mathrm{g} / \mathrm{mL}$ to $3.13 \mu \mathrm{g} / \mathrm{mL}$. Hence, it is a worthwhile adventure to exploit these compounds further to investigate their cytotoxicity profile so as to further harness and identify their potential for possible novel drug discovery. This is needful, especially, in a time like this when drug resistance challenge has become a strong toolbox for global health threat and undesirable avenue for high mortality rate among mankind and livestock.

\section{CONCLUSION}

The quinoline group has been proven to have remarkable utilities in medicinal chemistry as one of the most widely used antibiotics and antimalarials in the world. The microwave irradiation method showed to be very effective, cheap, fast and economical. It also promotes environmental friendly synthetic approach since the toxicity and hazardous discharges from chemical usage is not experienced and the synthesis was carried out successfully in a neat and green reaction medium. As envisaged, most of the novel hydrazide-hydrazones of quinoline were shown to have higher inhibitory potentials than the antibiotic standard, gentamicin used in most cases. 2-Propyl-(N'(1,7,7-trimethylbicyclo[2.2.1]heptan-2-ylidene)quinoline-4-carbohydrazide, $4 \mathbf{e}$ emerged as the most active antibacterial agent with MIC values ranging from 1.59 to $0.39 \mu \mathrm{g} / \mathrm{mL}$ on the six organisms tested.

\section{EXPERIMENTAL}

All chemical compounds were pure and of analytical grade. They were purchased from Sigma Aldrich, USA and except for cyclopentanone and isatin which were purchased BDH Chemicals, UK, but were made available by Department of Chemistry, Covenant University. Melting points were determined in open capillary tubes on Stuart melting point apparatus and were uncorrected. The Infrared spectra were run using the Perkin Elmer FT-IR Spectrophotometer (KBr pellet, 4000 $\mathrm{cm}^{-1}$ to $400 \mathrm{~cm}^{-1}$ ). The Ultraviolet-Visible (uv-vis.) spectrophotometric analyses of all the samples were run in either dichloromethane $\left(\mathrm{CH}_{2} \mathrm{Cl}_{2}\right)$, or Dimethyl sulphoxide (DMSO) solvents using UV-Genesys 10s v1.200 Spectrophotometer. The absorbance was plotted against the wavelength

$\lambda_{\max }(\mathrm{nm})$ and the obtained molar absorptivity was used to calculate Log $\varepsilon_{\max }$. The progress of the reaction and the level of purity of the compounds were routinely checked by Thin Layer Chromatography (TLC) on silica gel plates using different eluting solvent (solvent system) and 
the developed plates were visualized under UV light and in the iodine tank. Furthermore, the ${ }^{1} \mathrm{H}$ NMR and ${ }^{13} \mathrm{C}$ NMR spectra were recorded on NMR Bruker DPX 500 Spectrometer operating at the machine frequencies of $500 \mathrm{MHz}$ and $125 \mathrm{MHz}$ respectively using either $\mathrm{CDCl}_{3}$ or DMSO-d as solvent for sample preparation prior to analyses. In addition, DEPT-135 NMR analysis was also evaluated for all the synthesized compounds. Tetramethylsilane (TMS) was used as internal standard with the deuterium signal of the solvent as the lock and chemical shifts $\delta$ were recorded in ppm and the coupling constants $(J)$ were reported in Hertz $(\mathrm{Hz})$ where distinct multiplicities were observed. Standard abbreviation was used for the multiplicity which include singlet (s), doublet (d), triplet (t), quartet (q), multiplet (m) etc. The microwave assisted syntheses were carried out with the aid of CEM Discover Monomode oven operating at frequency of $2450 \mathrm{MHz}$ monitored by a PC computer and temperature control was fixed at $140{ }^{\circ} \mathrm{C}$ within the power modulation of $500 \mathrm{~W}$. The reactions were performed in sealed tube within ramp time of 1 to 3 min while stirring was provided by an in situ magnetic stirrer. In addition, $\mathrm{pH}$ was monitored and confirmed during acidification using $\mathrm{pH}$ meter model PHB4. All drying was conducted at reduced pressure with DHG-9023A Vacuum Oven. The elemental analysis $(\mathrm{C}, \mathrm{H}, \mathrm{N})$ of the synthesized compounds were performed using a Flash EA 1112 elemental analyzer. Results were found to be in good agreement with the calculated values (Table 1).

General procedure for microwave-assisted synthesis of hydrazide-hydrazone (4a-l). 2Propylquinoline-4-carbohydrazide, $3(3.0 \mathrm{~g}, 13 \mathrm{mmol})$ was dissolved in about $10 \mathrm{~mL}$ of ethanol in a $100 \mathrm{~mL}$ beaker covered with watch glass. The corresponding ketone $(13 \mathrm{mmol})$ was added and the beaker was swirled thoroughly for proper homogeneity. The resulting mixture was then irradiated in microwave oven for a period of 1 to $3 \mathrm{~min}$ as the case may be, based on the result obtained from the monitored progress of reaction using TLC spotting in dichloromethane (DCM) as eluting solvent. The heated solution was allowed to cool to ambient temperature and filtered to afford the corresponding hydrazide-hydrazone of quinoline (4a-1) in good to excellent yields after column chromatograph.

N'-(Butan-2-ylidene)-2-propylquinoline-4-carbohydrazide (4a). Microwave assisted reaction of 3 ( $3.0 \mathrm{~g}, 13 \mathrm{mmol})$ with butan-2-one ( $1.16 \mathrm{~mL}, 13 \mathrm{mmol})$ for $2 \mathrm{~min}$ afforded $N^{\prime}$-(butan2-ylidene)-2-propylquinoline-4-carbohydrazide, 4a as brown solid. Yield $3.25 \mathrm{~g}$ (82 \%); M.p. 258 ${ }^{\circ} \mathrm{C} ; \mathrm{C}_{17} \mathrm{H}_{21} \mathrm{~N}_{3} \mathrm{O}$ (283.87): Anal. Found: C, 72.06; H, 7.47; N, 14.83\% Calc.: C, 72.11; H, 7.52, N, 14.92\%. ${ }^{1} \mathrm{H}$ NMR $(\delta$, ppm in dmso-d $)$ ) 7.75-7.73 (d, $\left.J=10.0 \mathrm{~Hz}, 2 \mathrm{H}, \mathrm{Ar}-\mathrm{H}\right), 7.52$ (s, 1H, Ar-H), 7.29-7.26 (dd, $\left.J_{1}=10.0 \mathrm{~Hz}, J_{2}=12.5 \mathrm{~Hz}, 2 \mathrm{H}, \mathrm{Ar}-\mathrm{H}\right), 5.80(\mathrm{~s}, 1 \mathrm{H}, \mathrm{NH}), 3.73-3.72\left(\mathrm{~m}, 2 \mathrm{H}, \mathrm{CH}_{2}\right)$, $3.31-3.25$ (q, $\left.J=8.0 \mathrm{~Hz}, 2 \mathrm{H}, \mathbf{C H}_{2} \mathrm{CH}_{3}\right), 3.17-3.11$ (q, $\left.J=8.20 \mathrm{~Hz}, 2 \mathrm{H}, \mathbf{C H}_{2} \mathrm{CH}_{3}\right), 2.40(\mathrm{~s}, 3 \mathrm{H}$, $\left.\mathbf{C H}_{3}-\mathrm{C}=\mathrm{N}\right), 1.12-1.08\left(\mathrm{t}, J=8.0 \mathrm{~Hz}, 3 \mathrm{H}, \mathbf{C H}_{3} \mathrm{CH}_{2}\right), 1.02-0.99\left(\mathrm{t}, J=8.0 \mathrm{~Hz}, 3 \mathrm{H}, \mathbf{C H}_{3} \mathrm{CH}_{2}\right) .{ }^{13} \mathrm{C}$ $\operatorname{NMR}(\delta, \text { ppm in dmso-d })_{6}: 173.2(\mathrm{C}=\mathrm{O}), 158.4,151.2,141.9,135.0,132.3,127.4,120.8,117.0$, $116.8,110.0,41.3,29.3,25.3,20.2,15.1,10.1\left(\mathrm{CH}_{3}\right)$. DEPT $135(\delta$, ppm in dmso-d 6$)$ : Positive signals are $141.9(\mathrm{CH}), 135.0(\mathrm{CH}), 132.3(\mathrm{CH}), 117.0(\mathrm{CH}), 116.8(\mathrm{CH}), 20.2\left(\mathrm{CH}_{3}\right), 15.1\left(\mathrm{CH}_{3}\right)$, $10.1\left(\mathrm{CH}_{3}\right)$. Negative signals are 41.3, 29.3, $25.3\left(\mathrm{CH}_{2}\right)$. UV-Vis.: $\lambda_{\max }(\mathrm{nm}) / \log \varepsilon_{\max }\left(\mathrm{mol}^{-1} \mathrm{~cm}^{-1}\right)$ : 203 (4.04), 225 (4.08), 251 (4.10), 254 (4.38), 305 (4.11). IR ( $\left.\mathrm{cm}^{-1}\right)$ : vN-H 3415, vC-H aliph. 2981, vC=C 1633, vC-N 1140, $v$ =C-H bending 982.

N'-(Pentan-2-ylidene)-2-propylquinoline-4-carbohydrazide (4b). Microwave assisted reaction of 3 (3.0 g, $13 \mathrm{mmol})$ with pentan-2-one $(1.38 \mathrm{~mL}, 13 \mathrm{mmol})$ for $2 \mathrm{~min}$ afforded $N^{\prime}$ (pentan-2-ylidene)-2-propylquinoline-4-carbohydrazide, 4b as brown solid. Yield $3.16 \mathrm{~g}$ (76\%); 
M.p. 261-262 ${ }^{\circ} \mathrm{C} ; \mathrm{C}_{18} \mathrm{H}_{23} \mathrm{~N}_{3} \mathrm{O}$ (297.39): Anal. Found: C, 72.70; H, 7.80, N, 14.13\% Calc.: C, 72.65; $\mathrm{H}, 7.74 ; \mathrm{N}, 14.09 \% .{ }^{1} \mathrm{H}$ NMR $(\delta, \mathrm{ppm}$ in dmso-d 6$): 7.77-7.75(\mathrm{~d}, J=10.0 \mathrm{~Hz}, 2 \mathrm{H}, \mathrm{Ar}-\mathrm{H}), 7.75(\mathrm{~s}$, $1 \mathrm{H}, \mathrm{Ar}-\mathrm{H}), 7.28-7.26\left(\mathrm{dd}, J_{1}=10.0 \mathrm{~Hz}, J_{2}=12.5 \mathrm{~Hz}, 2 \mathrm{H}, \mathrm{Ar}-\mathrm{H}\right), 4.76(\mathrm{~s}, 1 \mathrm{H}, \mathrm{NH}), 3.53-3.48(\mathrm{q}$, $\left.J=8.5 \mathrm{~Hz}, 2 \mathrm{H}, \mathbf{C H}_{2} \mathrm{CH}_{3}\right), 3.34-3.29$ (q, $\left.J=8.9 \mathrm{~Hz}, 2 \mathrm{H}, \mathbf{C H}_{2} \mathrm{CH}_{3}\right), 2.40(\mathrm{~s}, 3 \mathrm{H}, \mathbf{C H}-\mathrm{C}=\mathrm{N}), 2.08$ $\left(\mathrm{m}, 2 \mathrm{H}, \mathrm{CH}_{2}\right), 1.86\left(\mathrm{~m}, 2 \mathrm{H}, \mathrm{CH}_{2}\right), 1.27-1.24\left(\mathrm{t}, J=8.90 \mathrm{~Hz}, 3 \mathrm{H}, \mathbf{C H}_{3} \mathrm{CH}_{2}\right), 1.10-1.06(\mathrm{t}, J=8.50$ $\left.\mathrm{Hz}, 3 \mathrm{H}, \mathbf{C H}_{3} \mathrm{CH}_{2}\right) .{ }^{13} \mathrm{C} \mathrm{NMR}(\delta, \mathrm{ppm}$ in dmso-d 6$)$ : $173.1(\mathrm{C}=\mathrm{O}), 158.8,151.3,141.9,135.0,132.3$, $127.4,120.8,117.0,116.8,110.0,41.3,33.3,29.3,25.3,20.2,15.1,10.1\left(\mathrm{CH}_{3}\right)$ ppm. DEPT 135 $\left(\delta\right.$, ppm in dmso-d $\mathrm{d}_{6}$ : Positive signals are $141.9(\mathrm{CH}), 135.0(\mathrm{CH}), 132.3(\mathrm{CH}), 117.0(\mathrm{CH})$, 116.8 $(\mathrm{CH}), 20.2\left(\mathrm{CH}_{3}\right), 15.1\left(\mathrm{CH}_{3}\right), 10.1\left(\mathrm{CH}_{3}\right)$. Negative signals are 41.3, 33.3, 29.3, $25.3\left(\mathrm{CH}_{2}\right)$. UV-Vis.: $\lambda_{\max }(\mathrm{nm}) / \log \varepsilon_{\max }\left(\mathrm{mol}^{-1} \mathrm{~cm}^{-1}\right): 225$ (4.10), 250 (4.31), 265 (4.45), 275 (4.75), 317 (4.61). IR $\left(\mathrm{cm}^{-1}\right)$ : vN-H 3358, vC-H arom. 3151, vC-H aliph. 2925, vC-H aliph. 2805, vC=O 1683, vC=C 1603, vC=N $1589, v_{\mathrm{CH}_{3}}$ deformation 1467, $v \mathrm{C}-\mathrm{N} 1248, v=\mathrm{C}-\mathrm{H}$ bending 982, $v$ Ar-H 749.

N'-(Hepta-2-ylidene)-2-propylquinoline-4-carbohydrazide (4c). Microwave assisted reaction of $3(3.0 \mathrm{~g}, 13 \mathrm{mmol})$ with heptan-2-one $(1.86 \mathrm{~mL}, 13 \mathrm{mmol})$ for $1 \frac{1 / 2}{\mathrm{~min}}$ afforded $N^{\prime}-$ (hepta-2-ylidene)-2-propylquinoline-4-carbohydrazide, $\mathbf{4 c}$ as brown solid. Yield $3.87 \mathrm{~g}(85 \%)$; M.p. 263-265 ${ }^{\circ} \mathrm{C} ; \mathrm{C}_{20} \mathrm{H}_{27} \mathrm{~N}_{3} \mathrm{O}$ (325.46): Anal. Found: C, 73.81; H, 8.36; N, 12.91\% Calc.: C, 73.71; $\mathrm{H}, 8.27$; N, 13.04\%. ${ }^{1} \mathrm{H}$ NMR $(\delta$, ppm in dmso-d 6 ): 7.58-7.56 (d, J=10.30 Hz, 2H, Ar-H), 7.21$7.19\left(\mathrm{dd}, J_{1}=10.5 \mathrm{~Hz}, J_{2}=10.9 \mathrm{~Hz}, 2 \mathrm{H}, \mathrm{Ar}-\mathrm{H}\right), 4.86(\mathrm{~s}, 1 \mathrm{H}, \mathrm{NH}), 3.73-3.70(\mathrm{q}, J=9.1 \mathrm{~Hz}, 2 \mathrm{H}$, $\mathbf{C H}_{2} \mathrm{CH}_{3}$ ), 3.31-3.26 (q, $J=8.9 \mathrm{~Hz}, 2 \mathrm{H}, \mathbf{C H}_{2} \mathrm{CH}_{3}$ ), 3.15-3.04 (m, 2H, $\mathrm{CH}_{2}$ ), 2.36 (s, 3H, $\mathbf{C H}_{3-}$ $\mathrm{C}=\mathrm{N}), 1.79-1.47\left(\mathrm{~m}, 6 \mathrm{H}, 3 \times \mathrm{CH}_{2}\right), 1.26-1.23\left(\mathrm{t}, J=8.9 \mathrm{~Hz}, 3 \mathrm{H}, \mathbf{C H}_{3} \mathrm{CH}_{2}\right), 0.96-0.93(\mathrm{t}, J=8.5$ $\left.\mathrm{Hz}, 3 \mathrm{H}, \mathbf{C H}_{3} \mathrm{CH}_{2}\right) .{ }^{13} \mathrm{C}$ NMR $\left.(\delta, \text { ppm in dmso-d })_{6}\right): 173.1(\mathrm{C}=\mathrm{O}), 158.8,151.3,141.9,135.0,132.3$, 127.4, 120.8, 117.0, 116.8, 110.0, 41.3, 33.3, 29.3, $28.5\left(2 \times \mathrm{CH}_{2}\right), 25.3,20.2,15.1,10.1\left(\mathrm{CH}_{3}\right)$. DEPT $135(\delta$, ppm in dmso-d 6$)$ : Positive signals are $141.9(\mathrm{CH}), 135.0(\mathrm{CH}), 132.3(\mathrm{CH}), 117.0$ $(\mathrm{CH}), 116.8(\mathrm{CH}), 20.2\left(\mathrm{CH}_{3}\right), 15.1\left(\mathrm{CH}_{3}\right), 10.1\left(\mathrm{CH}_{3}\right)$. Negative signals are 41.3, 33.3, 29.3, 28.5 $\left(2 \times \mathrm{CH}_{2}\right), 25.3\left(\mathrm{CH}_{2}\right)$. UV-Vis.: $\lambda_{\max }(\mathrm{nm}) / \log \varepsilon_{\max }\left(\mathrm{mol}^{-1} \mathrm{~cm}^{-1}\right): 208$ (3.85), 215 (3.90), 224 (3.98), 230 (4.11), 257 (4.46). IR ( $\left.\mathrm{cm}^{-1}\right)$ : vN-H 3411, vC-H aliph. 2957, vC-H aliph. 2931, vC-H aliph. 2861, vC=O $1668, v \mathrm{C}=\mathrm{C} 1638, v_{\mathrm{CH}_{3}}$ deformation $1460, v \mathrm{C}-\mathrm{N} 1123, v=\mathrm{C}-\mathrm{H}$ bending 982 , vAr-H 725 .

N'-(4-Methylpentan-2-ylidene)-2-propyl quinoline-4-carbohydrazide (4d). Microwave assisted reaction of $\mathbf{3}(3.0 \mathrm{~g}, 13 \mathrm{mmol})$ with 4-methylpentan-2-one (1.62 mL, $13 \mathrm{mmol})$ for $2 \mathrm{~min}$ afforded $N^{\prime}$-(4-methylpentan-2-ylidene)-2-propylquinoline-4-carbohydrazide, 4d as brown solid. Yield 3.05 g (70.00\%); M.p. $268{ }^{\circ} \mathrm{C} ; \mathrm{C}_{19} \mathrm{H}_{25} \mathrm{~N}_{3} \mathrm{O}$ (311.42): Anal. Found: C, 73.28; H, 8.09; N, 13.49\% Calc.: C, 73.12; H, 8.15; N, 13.58\%. ${ }^{1} \mathrm{H}$ NMR $(\delta$, ppm in dmso-d 6$): 7.74-7.72(\mathrm{~d}, J=10.0$ $\mathrm{Hz}, 2 \mathrm{H}, \mathrm{Ar}-\mathrm{H}), 7.51(\mathrm{~s}, 1 \mathrm{H}, \mathrm{Ar}-\mathrm{H}), 7.29-7.26\left(\mathrm{dd}, J_{1}=10.0 \mathrm{~Hz}, J_{2}=12.5 \mathrm{~Hz}, 2 \mathrm{H}, \mathrm{Ar}-\mathrm{H}\right), 5.80(\mathrm{~s}$, $1 \mathrm{H}, \mathrm{NH}), 3.73-3.72\left(\mathrm{~d}, J=7.2 \mathrm{~Hz}, 2 \mathrm{H}, \mathbf{C H} \mathbf{C H}_{2} \mathrm{CH}\right), 3.15-3.11\left(\mathrm{t}, J=8.5 \mathrm{~Hz}, 2 \mathrm{H}, \mathbf{C H}_{2} \mathrm{CH}_{2}\right), 2.40(\mathrm{~s}$, $\left.3 \mathrm{H}, \mathbf{C H}_{3}-\mathrm{C}=\mathrm{N}\right), 1.82-1.79(\mathrm{~m}, 1 \mathrm{H}, \mathrm{CH}), 1.71-1.67\left(\mathrm{~m}, 2 \mathrm{H}, \mathrm{CH}_{2}\right), 1.10-1.08(\mathrm{~d}, J=8.2 \mathrm{~Hz}, 6 \mathrm{H}, 2$ $\left.\times\left(\mathbf{C H}_{3}\right)_{2}-\mathrm{CH}\right), 0.99-0.97\left(\mathrm{t}, J=8.0 \mathrm{~Hz}, 3 \mathrm{H}, \mathbf{C H}_{3} \mathrm{CH}_{2}\right) .{ }^{13} \mathrm{C}$ NMR $\left(\delta, \mathrm{ppm}\right.$ in dmso-d $\left.\mathrm{d}_{6}\right): 173.2(\mathrm{C}=\mathrm{O})$, 158.4, 151.2, 141.9, 138.1, 128.7, 125.7, 120.8, 117.2, 115.3, 106.1, 44.2, 41.3, 29.3, 25.3, 21.3, $14.6\left(2 \times \mathrm{CH}_{3}\right), 10.1\left(\mathrm{CH}_{3}\right)$. DEPT $135(\delta, \mathrm{ppm}$ in dmso-d 6$)$ : Positive signals are $141.9(\mathrm{CH}), 138.1$ $(\mathrm{CH}), 128.7(\mathrm{CH}), 117.2(\mathrm{CH}), 115.3(\mathrm{CH}), 44.2(\mathrm{CH}), 21.3\left(\mathrm{CH}_{3}\right), 14.6\left(2 \times \mathrm{CH}_{3}\right), 10.1\left(\mathrm{CH}_{3}\right)$. Negative signals are 41.3, 29.3, $25.3\left(\mathrm{CH}_{2}\right)$. UV-Vis.: $\lambda_{\max }(\mathrm{nm}) / \log \varepsilon_{\max }\left(\mathrm{mol}^{-1} \mathrm{~cm}^{-1}\right): 217(4.24)$, 224 (4.05), 239 (4.26), 275 (4.62), 320 (4.45). IR (cm $\left.{ }^{-1}\right)$ : vN-H 3374, 3244, vC-H arom. 3036, vC-H aliph. 2980, $v \mathrm{C}-\mathrm{H}$ aliph. 2889, $v \mathrm{C}=\mathrm{C} 1688, v \mathrm{C}=\mathrm{C} 1605, v \mathrm{C}=\mathrm{N} 1587, v_{\mathrm{CH}} \mathrm{H}_{3}$ deformation $1464, v \mathrm{C}=\mathrm{N} 1243, v=\mathrm{C}-\mathrm{H}$ bending 965, vAr-H 774. 


\section{2-Propyl-(N'-(1,7,7-trimethylbicyclo[2.2.1]heptan-2-ylidene)quinoline-4-carbohydraz}

ide (4e). Microwave assisted reaction of $3(3.0 \mathrm{~g}, 13 \mathrm{mmol})$ with camphor $(1.99 \mathrm{~g}, 13 \mathrm{mmol})$ for 3 min afforded 2-propyl-( $N$ '-(1,7,7-trimethylbicyclo[2.2.1]heptan-2-ylidene)quinoline-4-carbohydr azide, 4e as white solid. Yield $3.92 \mathrm{~g}$, (77 \%); M.p. $>300{ }^{\circ} \mathrm{C} ; \mathrm{C}_{23} \mathrm{H}_{29} \mathrm{~N}_{3} \mathrm{O}$ (363.50): Anal. Found: C, 76.00; H, 8.04; N, 11.56\% Calc.: C, 75.88; H, 8.16; N, 11.66\%. ${ }^{1} \mathrm{H}$ NMR $(\delta$, ppm in dmso-d 6$)$ : 7.74-7.72 (d, $J=10.0 \mathrm{~Hz}, 2 \mathrm{H}, \mathrm{Ar}-\mathrm{H}), 7.51(\mathrm{~s}, 1 \mathrm{H}, \mathrm{Ar}-\mathrm{H}), 7.29-7.26\left(\mathrm{dd}, J_{1}=10.0 \mathrm{~Hz}, J_{2}=12.5\right.$ $\mathrm{Hz}, 2 \mathrm{H}, \mathrm{Ar}-\mathrm{H}), 5.84$ (s, 1H, NH), 3.78-3.77 (d, $J=4.8 \mathrm{~Hz}, 2 \mathrm{H}, \mathbf{C H} 2 \mathrm{CH}), 3.31-3.25$ (q, $J=7.4 \mathrm{~Hz}$, $\left.2 \mathrm{H}, \mathrm{CH}_{2} \mathbf{C H}_{2} \mathrm{CH}\right), 2.40$ (s, 3H, CH3-C=N), $2.12(\mathrm{~m}, 1 \mathrm{H}), 1.80(\mathrm{~m}, 2 \mathrm{H}), 1.67\left(\mathrm{~m}, 2 \mathrm{H}, \mathrm{CH}_{2}\right), 1.48$ $\left(\mathrm{t}, J=5.8 \mathrm{~Hz}, 2 \mathrm{H}, \mathbf{C H}_{2} \mathrm{CH}_{2}\right), 1.25\left(\mathrm{~s}, 6 \mathrm{H},(\mathbf{C H})_{2}-\mathrm{C}\right), 0.99\left(\mathrm{t}, J=6.2 \mathrm{~Hz}, 3 \mathrm{H}, \mathbf{C H}_{3} \mathrm{CH}_{2}\right) .{ }^{13} \mathrm{C} \mathrm{NMR}$ $(\delta$, ppm in dmso-d $)$ : $172.7(\mathrm{C}=\mathrm{O}), 159.6,151.0,142.7,134.9,132.3,127.4,120.8,117.0,116.8$, 110.4, 62.2, 44.0, 41.1, 29.8, 29.3, 25.3, 21.1, $15.1\left(2 \times \mathrm{CH}_{3}\right), 11.1\left(\mathrm{CH}_{3}\right)$. DEPT $135(\delta$, ppm in dmso-d $\left._{6}\right)$ : Positive signals are $142.7(\mathrm{CH}), 134.9(\mathrm{CH}), 132.3(\mathrm{CH}), 117.0(\mathrm{CH}), 116.8(\mathrm{CH}), 44.0$ $(\mathrm{CH}), 21.1\left(\mathrm{CH}_{3}\right), 15.1\left(2 \times \mathrm{CH}_{3}\right), 11.1\left(\mathrm{CH}_{3}\right)$. Negative signals are 62.1, 41.1, 29.8, 29.3, 25.3 $\left(\mathrm{CH}_{2}\right)$. UV-Vis.: $\lambda_{\max }(\mathrm{nm}) / \log \varepsilon_{\max }\left(\mathrm{mol}^{-1} \mathrm{~cm}^{-1}\right): 215$ (3.34), 236 (3.11), 431 (3.00), 437 (3.00). IR $\left(\mathrm{cm}^{-1}\right)$ : vN-H 3415, vC-H aliph. 2949, vC-H aliph. 2935, vC-H aliph. 2883, vC=O 1688, vC=C 1620, $v_{C H}$ deformation 1461, vC-N 1245, v =C-H bending 966, vAr-H 728.

N'-(2-Oxoindolin-3-ylidene)-2-propylquinoline-4-carbohydrazide (4f). Microwave assisted reaction of 3 (3.0 g, $13 \mathrm{mmol})$ with isatin $(1.91 \mathrm{~g}, 13 \mathrm{mmol})$ for $3 \mathrm{~min}$ afforded $N^{\prime}-(2-$ oxoindolin-3-ylidene)-2-propylquinoline-4-carbohydrazide, $\mathbf{4 f}$ as red solid. Yield $4.72 \mathrm{~g}$, (94\%); M.p. $>300{ }^{\circ} \mathrm{C} ; \mathrm{C}_{21} \mathrm{H}_{18} \mathrm{~N}_{4} \mathrm{O}$ (358.39): Anal. Found: C, 70.21; H, 4.94; N, 15.48\% Calc.: C, 70.38; $\mathrm{H}, 5.06 ; \mathrm{N}, 15.63 \% .{ }^{1} \mathrm{H}$ NMR $(\delta$, ppm in dmso-d 6$): 7.98-7.96(\mathrm{~d}, J=8.2 \mathrm{~Hz}, 1 \mathrm{H}, \mathrm{Ar}-\mathrm{H}), 7.83-7.81$ $(\mathrm{d}, J=8.4 \mathrm{~Hz}, 1 \mathrm{H}, \mathrm{Ar}-\mathrm{H}), 7.74-7.72(\mathrm{~d}, J=10.0 \mathrm{~Hz}, 2 \mathrm{H}, \mathrm{Ar}-\mathrm{H}), 7.51$ (s, 1H, Ar-H), 7.44-7.40 (m, $2 \mathrm{H}, \mathrm{Ar}-\mathrm{H}), 7.29-7.26\left(\mathrm{dd}, J_{1}=10.0 \mathrm{~Hz}, J_{2}=12.50 \mathrm{~Hz}, 2 \mathrm{H}, \mathrm{Ar}-\mathrm{H}\right), 6.01(\mathrm{~s}, 1 \mathrm{H}, \mathrm{NH}), 5.80(\mathrm{~s}, 1 \mathrm{H}$, $\mathrm{NH}), 3.15-3.13\left(\mathrm{t}, J=8.5 \mathrm{~Hz}, 2 \mathrm{H}, \mathbf{C H}_{2} \mathrm{CH}_{2}\right), 1.71-1.67\left(\mathrm{~m}, 2 \mathrm{H}, \mathrm{CH}_{2}\right), 0.99$ (t, $J=8.0 \mathrm{~Hz}, 3 \mathrm{H}$, $\left.\mathbf{C H}_{3} \mathrm{CH}_{2}\right) .{ }^{13} \mathrm{C}$ NMR $\left(\delta, \mathrm{ppm}\right.$ in dmso-d $\left.{ }_{6}\right): 180.0(\mathrm{C}=\mathrm{O}), 173.2(\mathrm{C}=\mathrm{O}), 158.4,151.2,146.9,141.9$, 135.9, 135.3, 132.8, 131.9, 127.4, 126.6, 121.7, 120.4, 117.3, 116.7, 110.2, 109.1, 29.7, 25.5, 10.1 $\left(\mathrm{CH}_{3}\right)$. DEPT $135(\delta, \mathrm{ppm}$ in dmso-d $)$ : Positive signals are $141.9(\mathrm{CH}), 135.9(\mathrm{CH}), 135.3(\mathrm{CH})$, $132.8(\mathrm{CH}), 131.9(\mathrm{CH}), 121.7(\mathrm{CH}), 120.4(\mathrm{CH}), 117.3(\mathrm{CH}), 116.7(\mathrm{CH}), 10.5\left(\mathrm{CH}_{3}\right)$. Negative signals are $29.7\left(\mathrm{CH}_{2}\right), 25.5\left(\mathrm{CH}_{2}\right)$. UV-Vis.: $\lambda_{\max }(\mathrm{nm}) / \log \varepsilon_{\max }\left(\mathrm{mol}^{-1} \mathrm{~cm}^{-1}\right): 212(4.08), 225$ (4.09), 236 (4.25), 257 (4.73), 314 (4.50). IR ( $\left.\mathrm{cm}^{-1}\right)$ : vN-H 3415, vN-H 3281, vC-H arom. 3053, vC-H arom. 3020, vC-H aliph. 2854, vC $=\mathrm{O} 1723, v \mathrm{C}=\mathrm{O} 1688, v_{\mathrm{C}}=\mathrm{C} 1614, v \mathrm{CH}_{3}$ deformation 1463, vC-N 1254, $v=\mathrm{C}-\mathrm{H}$ bending 985, vAr-H 752.

N'-(3-Oxoheptan-2-ylidene)-2-propylquinoline-4-carbohydrazide (4g). Microwave assisted reaction of $3(3.0 \mathrm{~g}, 13 \mathrm{mmol})$ with heptane-2,3-dione $(1.79 \mathrm{~mL}, 13 \mathrm{mmol})$ for $3 \mathrm{~min}$ afforded $N^{\prime}$-(3-oxoheptan-2-ylidene)-2-propylquinoline-4-carbohydrazide, $\mathbf{4 g}$ as brown solid. Yield 3.85 g, (81 \%); M.p. 290-291 ${ }^{\circ} \mathrm{C}$; $\mathrm{C}_{20} \mathrm{H}_{25} \mathrm{~N}_{3} \mathrm{O}_{3}$ (339.43): Anal. Found: C, 71.01; H, 7.59; N, 12.55\% Calc.: C, 70.77; H, 7.42; N, 12.38\%. ${ }^{1} \mathrm{H}$ NMR $\left(\delta\right.$, ppm in dmso-d $\left.\mathrm{d}_{6}\right): 7.75-7.73(\mathrm{~d}, J=10.2$ $\mathrm{Hz}, 2 \mathrm{H}, \mathrm{Ar}-\mathrm{H}), 7.55(\mathrm{~s}, 1 \mathrm{H}, \mathrm{Ar}-\mathrm{H}), 7.29-7.26\left(\mathrm{dd}, J_{1}=6.4 \mathrm{~Hz}, J_{2}=10.2 \mathrm{~Hz}, 2 \mathrm{H}, \mathrm{Ar}-\mathrm{H}\right), 5.80(\mathrm{~s}$, $1 \mathrm{H}, \mathrm{NH}), 3.73-3.70\left(\mathrm{t}, J=6.1 \mathrm{~Hz}, 2 \mathrm{H}, \mathbf{C H}_{2} \mathrm{CH}_{2}\right), 3.31-3.25$ (q, $\left.J=6.9 \mathrm{~Hz}, 2 \mathrm{H}, \mathrm{CH}_{2}\right), 3.15-3.04$ $\left(\mathrm{m}, 2 \mathrm{H}, \mathrm{CH}_{2}\right), 2.36(\mathrm{~s}, 3 \mathrm{H}, \mathbf{C H}-\mathrm{C}=\mathrm{N}), 1.80-1.75\left(\mathrm{~m}, 4 \mathrm{H}, 2 \times \mathrm{CH}_{2}\right), 1.12-1.08(\mathrm{t}, J=6.1 \mathrm{~Hz}, 3 \mathrm{H}$, $\left.\mathbf{C H}_{3} \mathrm{CH}_{2}\right), 1.02-0.99\left(\mathrm{t}, J=6.4 \mathrm{~Hz}, 3 \mathrm{H}, \mathbf{C H}_{3} \mathrm{CH}_{2}\right) .{ }^{13} \mathrm{C} \mathrm{NMR}(\delta, \mathrm{ppm}$ in dmso-d 6$): 173.3(\mathrm{C}=\mathrm{O})$, $172.5(\mathrm{C}=\mathrm{O}), 159.6,151.0,142.7,134.9,132.3,127.4,120.8,117.0,116.8,110.4,62.2,41.1,29.8$, 29.3, 25.3, $20.2\left(\mathrm{CH}_{3}\right), 15.1\left(\mathrm{CH}_{3}\right), 11.1\left(\mathrm{CH}_{3}\right)$. DEPT $135\left(\delta, \mathrm{ppm}\right.$ in dmso- $\left.\mathrm{d}_{6}\right)$ : Positive signals are $142.7(\mathrm{CH}), 134.9(\mathrm{CH}), 132.3(\mathrm{CH}), 117.0(\mathrm{CH}), 116.8(\mathrm{CH}), 20.2\left(\mathrm{CH}_{3}\right), 15.1\left(\mathrm{CH}_{3}\right), 11.1$ 
$\left(\mathrm{CH}_{3}\right)$. Negative signals are 62.2, 41.1, 29.8, 29.3, $25.3\left(\mathrm{CH}_{2}\right) . \mathrm{UV}-\mathrm{Vis} .: \lambda_{\max }(\mathrm{nm}) / \log \varepsilon_{\max }\left(\mathrm{mol}^{-}\right.$ $\left.{ }^{1} \mathrm{~cm}^{-1}\right)$ : 215 (4.33), 224 (4.43), 240 (4.33), 253 (4.49), 257 (5.14). IR ( $\left.\mathrm{cm}^{-1}\right): \mathrm{vN}-\mathrm{H} 3411, v \mathrm{C}-\mathrm{H}$ arom.3010, vC-H aliph. 2929, vC-H aliph. 2891, vC $=\mathrm{O} 1715, v_{C}=\mathrm{O} 1688, v_{C}=\mathrm{C} 1620, v_{C H}$ deformation 1461, vC-N $1244, v=\mathrm{C}-\mathrm{H}$ bending $967, \mathrm{vAr}-\mathrm{H} 725$.

N'-Cyclopentylidene-2-propylquinoline-4-carbohydrazide (4h). Microwave assisted reaction of 3 ( $3.0 \mathrm{~g}, 13 \mathrm{mmol})$ with cyclopentanone $(1.15 \mathrm{ml}, 13 \mathrm{mmol})$ for $1 \frac{1}{2} 2 \mathrm{~min}$ afforded $N^{\prime}-$ cyclopentylidene-2-propylquinoline-4-carbohydrazide, 4h as black solid. Yield $3.68 \mathrm{~g}$, (89 \%); M.p. $255^{\circ} \mathrm{C} ; \mathrm{C}_{18} \mathrm{H}_{21} \mathrm{~N}_{3} \mathrm{O}$ (295.38): Anal. Found: C, 72.99; H, 6.97; N, 14.39\% Calc.: C, 73.19; H, 7.17; N, 14.23\%. ${ }^{1} \mathrm{H}$ NMR ( $\delta$, ppm in dmso-d $)$ ): 7.75-7.73 (d, J=10.2 Hz, 2H, Ar-H), 7.55 (s, 1H, Ar-H), 7.29-7.26 (dd, $\left.J_{1}=6.6 \mathrm{~Hz}, J_{2}=10.2 \mathrm{~Hz}, 2 \mathrm{H}, \mathrm{Ar}-\mathrm{H}\right), 5.80(\mathrm{~s}, 1 \mathrm{H}, \mathrm{NH}), 3.76-3.72(\mathrm{t}, J=7.4$ $\left.\mathrm{Hz}, 4 \mathrm{H}, 2 \times \mathbf{C H}_{2} \mathrm{CH}_{2}\right), 3.31-3.27\left(\mathrm{t}, J=5.6 \mathrm{~Hz}, 2 \mathrm{H}, \mathrm{CH}_{2}\right), 3.17-3.13\left(\mathrm{~m}, 2 \mathrm{H}, \mathrm{CH}_{2}\right), 1.80-1.75(\mathrm{~m}$, $\left.4 \mathrm{H}, 2 \times \mathrm{CH}_{2}\right), 1.02-0.99\left(\mathrm{t}, J=6.2 \mathrm{~Hz}, 3 \mathrm{H}, \mathbf{C H}_{3} \mathrm{CH}_{2}\right) .{ }^{13} \mathrm{C} \mathrm{NMR}\left(\delta, \mathrm{ppm}\right.$ in dmso-d $\left.{ }_{6}\right): 172.5(\mathrm{C}=\mathrm{O})$, 159.6, 151.0, 142.7, 134.9, 132.3, 127.4, 120.8, 117.0, 116.8, 110.4, 61.9, 41.2, $35.8\left(2 \times \mathrm{CH}_{2}\right)$, 29.6, 24.7, $13.4\left(\mathrm{CH}_{3}\right)$. DEPT $135(\delta$, ppm in dmso-d 6$)$ : Positive signals are $142.7(\mathrm{CH}), 134.9$ $(\mathrm{CH}), 132.3(\mathrm{CH}), 117.0(\mathrm{CH}), 116.8(\mathrm{CH}), 13.4\left(\mathrm{CH}_{3}\right)$. Negative signals are 61.9, 41.2, $35.8(2 \times$ $\left.\mathrm{CH}_{2}\right)$, 29.6, $24.7\left(2 \times \mathrm{CH}_{2}\right)$. UV-Vis.: $\lambda_{\max }(\mathrm{nm}) / \log \varepsilon_{\max }\left(\mathrm{mol}^{-1} \mathrm{~cm}^{-1}\right): 207$ (3.79), 213 (3.79), 227 (4.13), 254 (4.39), 308 (4.11). IR ( $\left.\mathrm{cm}^{-1}\right): v_{\mathrm{N}-\mathrm{H}} 3415$, vC-H arom. 3030, vC-H aliph. 2930, vC-H aliph. 2865, $v \mathrm{C}=\mathrm{O} 1688, v \mathrm{C}=\mathrm{C} 1605, v \mathrm{CN} 1575, v_{\mathrm{CH}_{3}}$ deformation $1467, v_{C H}$ deformation $1355, v \mathrm{C}-\mathrm{N} 1248, v=\mathrm{C}-\mathrm{H} 965, v \mathrm{Ar}-\mathrm{H}$ 725.

N'-Cyclohexylidene-2-propylquinoline-4-carbohydrazide (4i). Microwave assisted reaction of $3(3.0 \mathrm{~g}, 13 \mathrm{mmol})$ with cyclohexanone $(1.35 \mathrm{~mL}, 13 \mathrm{mmol})$ for $2^{1 / 2} \mathrm{~min}$ afforded $N^{\prime}$ cyclohexylidene-2-propylquinoline-4-carbohydrazide, 4i as brown solid. Yield $3.54 \mathrm{~g}$ (88\%); M.p. 257-258 ${ }^{\circ} \mathrm{C} ; \mathrm{C}_{19} \mathrm{H}_{23} \mathrm{~N}_{3} \mathrm{O}$ (309.39): Anal. Found: $\mathrm{C}$, 73.59; H, 7.31; N, 13.77\% Calc.: C, 73.76; H, 7.49; N, 13.58\%. ${ }^{1} \mathrm{H}$ NMR ( $\delta$, ppm in dmso-d 6$): 7.75-7.73(\mathrm{~d}, J=10.2 \mathrm{~Hz}, 2 \mathrm{H}, \mathrm{Ar}-\mathrm{H}), 7.55(\mathrm{~s}, 1 \mathrm{H}$, Ar-H), 7.29-7.26 (dd, $\left.J_{1}=6.6 \mathrm{~Hz}, J_{2}=10.2 \mathrm{~Hz}, 2 \mathrm{H}, \mathrm{Ar}-\mathrm{H}\right), 5.80(\mathrm{~s}, 1 \mathrm{H}, \mathrm{NH}), 3.76-3.72(\mathrm{t}, J=7.4$ $\left.\mathrm{Hz}, 4 \mathrm{H}, 2 \times \mathbf{C H}_{2} \mathrm{CH}_{2}\right), 3.31-3.27\left(\mathrm{t}, J=5.6 \mathrm{~Hz}, 2 \mathrm{H}, \mathrm{CH}_{2}\right), 3.17-3.13\left(\mathrm{~m}, 2 \mathrm{H}, \mathrm{CH}_{2}\right), 1.80-1.75(\mathrm{~m}$, $\left.4 \mathrm{H}, 2 \times \mathrm{CH}_{2}\right), 1.25-1.22\left(\mathrm{~m}, 2 \mathrm{H}, \mathrm{CH}_{2}\right), 1.02-0.99\left(\mathrm{t}, J=6.2 \mathrm{~Hz}, 3 \mathrm{H}, \mathbf{C H}_{3} \mathrm{CH}_{2}\right) .{ }^{13} \mathrm{C} \mathrm{NMR}(\delta, \mathrm{ppm}$ in dmso-d $)^{2}: 172.4(\mathrm{C}=\mathrm{O}), 159.5,151.0,142.6,135.0,132.4,127.4,120.8,117.2,116.8,110.4$, 61.9, 41.2, $35.8\left(2 \times \mathrm{CH}_{2}\right), 29.6,24.7,20.7,13.9\left(\mathrm{CH}_{3}\right)$. DEPT 135 ( $\delta$, ppm in dmso-d 6$)$ : Positive signals are 142.6 $(\mathrm{CH}), 135.0(\mathrm{CH}), 132.4(\mathrm{CH}), 117.2(\mathrm{CH}), 116.8(\mathrm{CH}), 13.9\left(\mathrm{CH}_{3}\right)$. Negative signals are $61.9,41.2,35.8\left(2 \times \mathrm{CH}_{2}\right), 29.6,24.7,20.7$. UV-Vis.: $\lambda_{\max }(\mathrm{nm}) / \log \varepsilon_{\max }\left(\mathrm{mol}^{-1} \mathrm{~cm}^{-1}\right)$ : 209 (4.57), 272 (5.42), 323 (5.25). IR ( $\left.\mathrm{cm}^{-1}\right)$ : vN-H 3411, vC-H arom. 3025, vC-H aliph. 2929, vC-H aliph. 2875, vC=O 1688, vC=C 1607, $v \mathrm{C}=\mathrm{N} 1575, v \mathrm{CH}_{3}$ deformation 1465, $v_{\mathrm{CH}} 1360, v \mathrm{C}-\mathrm{N} 1245, v=\mathrm{C}-\mathrm{H}$ bending 987 , vAr-H 722.

N'-Cycloheptylidene-2-propylquinoline-4-carbohydrazide (4j). Microwave assisted reaction of $3(3.0 \mathrm{~g}, 13 \mathrm{mmol})$ with cycloheptanone $(1.54 \mathrm{~mL}, 13 \mathrm{mmol})$ for $2 \frac{1}{2} \mathrm{~min}$ afforded $N^{\prime}$ cycloheptylidene-2-propylquinoline-4-carbohydrazide, $\mathbf{4 j}$ as brown solid. Yield $3.74 \mathrm{~g} \mathrm{(89 \% );}$ M.p. 261-263 ${ }^{\circ} \mathrm{C} ; \mathrm{C}_{20} \mathrm{H}_{25} \mathrm{~N}_{3} \mathrm{O}$ (323.43): Anal. Found: C, 74.19; H, 7.95; N, 13.08\% Calc.: C, 74.27; $\mathrm{H}, 7.79 ; \mathrm{N}, 12.99 \% .{ }^{1} \mathrm{H}$ NMR $(\delta$, ppm in dmso-d 6$)$ : 7.75-7.73 (d, J=10.2 Hz, 2H, Ar-H), 7.55 (s, $1 \mathrm{H}, \mathrm{Ar}-\mathrm{H}), 7.29-7.26\left(\mathrm{dd}, J_{1}=6.6 \mathrm{~Hz}, J_{2}=10.2 \mathrm{~Hz}, 2 \mathrm{H}, \mathrm{Ar}-\mathrm{H}\right), 5.80(\mathrm{~s}, 1 \mathrm{H}, \mathrm{NH}), 3.73(\mathrm{t}, J=7.8$ $\left.\mathrm{Hz}, 4 \mathrm{H}, 2 \times \mathbf{C H}_{2} \mathrm{CH}_{2}\right), 3.31-3.27\left(\mathrm{t}, J=5.6 \mathrm{~Hz}, 2 \mathrm{H}, \mathrm{CH}_{2}\right), 3.17-3.13\left(\mathrm{~m}, 2 \mathrm{H}, \mathrm{CH}_{2}\right), 1.80-1.75(\mathrm{~m}$, $\left.4 \mathrm{H}, 2 \times \mathrm{CH}_{2}\right), 1.40\left(\mathrm{~m}, 2 \mathrm{H}, \mathrm{CH}_{2}\right), 1.25-1.22\left(\mathrm{~m}, 2 \mathrm{H}, \mathrm{CH}_{2}\right), 1.02-0.99$ (t, J=6.2 Hz, 3H, $\left.\mathbf{C H}_{3} \mathrm{CH}_{2}\right)$. ${ }^{13} \mathrm{C}$ NMR $(\delta$, ppm in dmso-d $): 172.4(\mathrm{C}=\mathrm{O}), 159.4,151.0,142.5,135.0,132.2,127.5,120.8$, 
117.2, 116.7, 110.6, 61.5, 41.2, $35.8\left(2 \times \mathrm{CH}_{2}\right), 29.6\left(2 \times \mathrm{CH}_{2}\right), 24.7,20.7,13.9\left(\mathrm{CH}_{3}\right)$. DEPT 135 $\left(\delta\right.$, ppm in dmso-d $\left.{ }_{6}\right)$ : Positive signals are $142.6(\mathrm{CH}), 135.0(\mathrm{CH}), 132.4(\mathrm{CH}), 117.2(\mathrm{CH}), 116.8$ $(\mathrm{CH}), 13.9\left(\mathrm{CH}_{3}\right)$. Negative signals are 61.9, 41.2, $35.8\left(2 \times \mathrm{CH}_{2}\right), 29.6\left(2 \times \mathrm{CH}_{2}\right), 27.7,24.5,20.9$. UV-Vis.: $\lambda_{\max }(\mathrm{nm}) / \log \varepsilon_{\max }\left(\mathrm{mol}^{-1} \mathrm{~cm}^{-1}\right): 209$ (4.55), 251 (4.45), 296 (4.28), 314 (4.07). IR (cm-

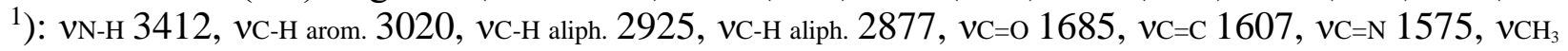
deformation $1465, v_{\mathrm{CH}_{2}} 1362, v \mathrm{C}-\mathrm{N} 1245, v=\mathrm{C}-\mathrm{H}$ bending $985, v \mathrm{Ar}-\mathrm{H} 722$.

$N^{\prime}$-(1-(4-ethylphenyl)ethylidene)-2-propylquinoline-4-carbohydrazide (4k). Microwave assisted reaction of $\mathbf{3}(3.0 \mathrm{~g}, 13 \mathrm{mmol})$ with 4-ethylacetophenone $(1.94 \mathrm{~mL}, 13 \mathrm{mmol})$ for $2 \mathrm{~min}$ afforded $N^{\prime}$-(1-(4-ethylphenyl)ethylidene)-2-propylquinoline-4-carbohydrazide, $4 \mathbf{k}$ as black solid. Yield 4.25 g, (91\%); M.p. 241-243 ${ }^{\circ} \mathrm{C} ; \mathrm{C}_{23} \mathrm{H}_{25} \mathrm{~N}_{3} \mathrm{O}$ (359.46): Anal. Found: C, 76.78; H, 6.88; N, $11.81 \%$ Calc.: C, $76.85 ; \mathrm{H}, 7.01 ; \mathrm{N}, 11.69 \% .{ }^{1} \mathrm{H}$ NMR $(\delta, \mathrm{ppm}$ in dmso-d 6 ): 7.98-7.96 (d, $J=8.0$ $\mathrm{Hz}, 2 \mathrm{H}, \mathrm{Ar}-\mathrm{H}$ ), 7.75-7.72 (d, $J=10.2 \mathrm{~Hz}, 2 \mathrm{H}, \mathrm{Ar}-\mathrm{H}), 7.61-7.59$ (d, $J=8.2 \mathrm{~Hz}, 2 \mathrm{H}, \mathrm{Ar}-\mathrm{H}), 7.52$ (s, $1 \mathrm{H}, \mathrm{Ar}-\mathrm{H}), 7.29-7.26(\mathrm{~m}, 2 \mathrm{H}, \mathrm{Ar}-\mathrm{H}), 5.80(\mathrm{~s}, 1 \mathrm{H}, \mathrm{NH}), 3.31-3.25\left(\mathrm{q}, J=7.6 \mathrm{~Hz}, 2 \mathrm{H}, \mathbf{C H}_{2} \mathrm{CH}_{3}\right)$, 3.17-3.11 (q, $\left.J=6.8 \mathrm{~Hz}, 2 \mathrm{H}, \mathbf{C H}_{2} \mathrm{CH}_{2}\right), 2.40\left(\mathrm{~s}, 3 \mathrm{H}, \mathbf{C H}_{3}-\mathrm{C}=\mathrm{N}\right), 1.80-1.74\left(\mathrm{~m}, 2 \mathrm{H}, \mathrm{CH}_{2}\right), 1.12-$ $1.08\left(\mathrm{t}, J=7.6 \mathrm{~Hz}, 3 \mathrm{H}, \mathbf{C H}_{3} \mathrm{CH}_{2}\right), 1.02-0.99\left(\mathrm{t}, J=6.5 \mathrm{~Hz}, 3 \mathrm{H}, \mathbf{C H}_{3} \mathrm{CH}_{2}\right) .{ }^{13} \mathrm{C} \mathrm{NMR}(\delta$, ppm in dmso- $\left._{6}\right): 172.5(\mathrm{C}=\mathrm{O}), 159.6,151.0,146.6(2 \times \mathrm{CH}), 142.7,134.9,132.3,127.4,124.1(2 \times \mathrm{CH})$, 120.8, 117.0, 116.8, 110.4, 54.1, 29.7, 25.4, $20.1\left(\mathrm{CH}_{3}\right), 15.3\left(\mathrm{CH}_{3}\right), 13.4\left(\mathrm{CH}_{3}\right)$. DEPT $135(\delta$, ppm in dmso-d 6 ): Positive signals are $146.6(2 \times \mathrm{CH}), 142.7(\mathrm{CH}), 134.9(\mathrm{CH}), 132.3(\mathrm{CH}), 124.1$ $(2 \times \mathrm{CH}), 117.0(\mathrm{CH}), 116.8(\mathrm{CH}), 20.1\left(\mathrm{CH}_{3}\right), 15.3\left(\mathrm{CH}_{3}\right), 13.4\left(\mathrm{CH}_{3}\right)$. Negative signals are 54.1 $\left(\mathrm{CH}_{2}\right), 29.7\left(\mathrm{CH}_{2}\right), 25.4\left(\mathrm{CH}_{2}\right)$. UV-Vis.: $\lambda_{\max }(\mathrm{nm}) / \log \varepsilon_{\max }\left(\mathrm{mol}^{-1} \mathrm{~cm}^{-1}\right): 209$ (4.55), $236(4.45)$, 269 (4.28), 314 (4.07). IR $\left(\mathrm{cm}^{-1}\right)$ : vN-H 3356, vC-H arom.3050, vC-H aliph. 2925, vC-H aliph. 2804, vC=O 1684, $v_{\mathrm{C}}=\mathrm{C} 1620, v_{\mathrm{C}=\mathrm{C}} 1605, v_{\mathrm{C}=\mathrm{N}} 1589, v_{\mathrm{CH}} \mathrm{H}_{3}$ deformation 1461, $v_{\mathrm{C}-\mathrm{N}} 1248, v=\mathrm{C}-\mathrm{H}$ bending $984, v_{\mathrm{Ar}-\mathrm{H}} 745$.

\section{$N^{\prime}$-(1-(2-oxo-2H-chromen-3-yl)ethylidene)-2-propylquinoline-4-carbohydrazide}

(4l). .Microwave assisted reaction of $\mathbf{3}(3.0 \mathrm{~g}, 13 \mathrm{mmol})$ with 3-acetylcoumarin $(2.44 \mathrm{~g}, 13 \mathrm{mmol})$ for 3 min afforded $N^{\prime}$-(1-(2-oxo- $2 H$-chromen-3-yl)ethylidene)-2-propylquinoline-4-carbohydrazide, $4 \mathrm{l}$ as yellow solid. Yield $4.41 \mathrm{~g},(85 \%)$; M.p. $>300{ }^{\circ} \mathrm{C} ; \mathrm{C}_{24} \mathrm{H}_{21} \mathrm{~N}_{3} \mathrm{O}_{3}$ (399.44): Anal. Found: C, 72.22; H, 5.19; N, 10.71\% Calc.: C, 72.16; H, 5.30; N, 10.52\%. ${ }^{1} \mathrm{H}$ NMR ( $\delta$, ppm in dmso- $\left.\mathrm{d}_{6}\right)$ : 8.64 (s, 1H, Het-H), 7.96-7.94 (d, $J=8.0 \mathrm{~Hz}, 1 \mathrm{H}, \mathrm{Ar}-\mathrm{H}), 7.75-7.72(\mathrm{~d}, J=10.2 \mathrm{~Hz}, 2 \mathrm{H}, \mathrm{Ar}-\mathrm{H})$, 7.70-7.66 (m, 2H, Ar-H), 7.52 (s, 1H, Ar-H), 7.29-7.26 (dd, $J_{1}=10.20 \mathrm{~Hz}, J_{2}=12.50 \mathrm{~Hz}, 2 \mathrm{H}, \mathrm{Ar}-$ $\mathrm{H}), 5.80$ (s, $1 \mathrm{H}, \mathrm{NH}), 3.31-3.27$ (t, $\left.J=6.8 \mathrm{~Hz}, 2 \mathrm{H}, \mathbf{C H}_{2} \mathrm{CH}_{2}\right), 2.40$ (s, $\left.3 \mathrm{H}, \mathbf{C H}-\mathrm{C}=\mathrm{N}\right), 1.80-1.74$ $\left(\mathrm{m}, 2 \mathrm{H}, \mathrm{CH}_{2}\right), 1.02-0.99\left(\mathrm{t}, J=6.8 \mathrm{~Hz}, 3 \mathrm{H}, \mathbf{C H}_{3} \mathrm{CH}_{2}\right) .{ }^{13} \mathrm{C}$ NMR $(\delta, \mathrm{ppm}$ in dmso-d 6 ): $177.2(\mathrm{C}=\mathrm{O})$, $172.5(\mathrm{C}=\mathrm{O}), 161.5,159.6,155.2,151.0,142.7,139.1,135.2,134.9,132.3,129.2,127.4,120.8$, 117.0, 116.8, $114.0(2 \times \mathrm{CH}), 111.9,110.4,54.1,29.7,20.1\left(\mathrm{CH}_{3}\right), 13.4\left(\mathrm{CH}_{3}\right)$. DEPT $135(\delta, \mathrm{ppm}$ in dmso-d 6 ): Positive signals are 161.5, 155.2, $142.7(\mathrm{CH}), 134.9(\mathrm{CH}), 132.3(\mathrm{CH}), 129.2117 .0$ $(\mathrm{CH}), 116.8(\mathrm{CH}), 114.0(2 \times \mathrm{CH}), 20.1\left(\mathrm{CH}_{3}\right), 13.4\left(\mathrm{CH}_{3}\right)$. Negative signals are $54.1\left(\mathrm{CH}_{2}\right), 29.7$ $\left(\mathrm{CH}_{2}\right)$. UV-Vis.: $\lambda_{\max }(\mathrm{nm}) / \log \varepsilon_{\max }\left(\mathrm{mol}^{-1} \mathrm{~cm}^{-1}\right): 215$ (4.06), 221 (4.44), 251 (4.68), 317 (4.09),

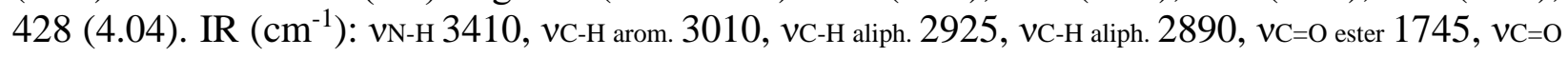
$1685, v \mathrm{C}=\mathrm{C} 1620, v \mathrm{C}=\mathrm{N} 1575, v_{\mathrm{CH}}$ deformation 1460, $v_{\mathrm{C}-\mathrm{N}} 1243, v=\mathrm{C}-\mathrm{H} 968, v_{\mathrm{Ar}-\mathrm{H}} 725$.

Antimicrobial activity assay. The antimicrobial assay of the compounds 4a-l was investigated against six organisms namely: Staphylococcus aureus, Bacillus lichenformis, Micrococcus varians. Escherichia coli, Proteus vulgaris and Pseudomonas aeruginosa. Antibacterial sensitivity testing was carried out on using agar diffusion method while minimum inhibitory concentration 
(MIC) test was determined by serial dilution method as described by a standard method [25] as shown in the supplementary information.

Supplementary Information (SI). Supplementary file contains detailed procedures for the synthesis of precursor $\mathbf{1}$, reactive intermediates $\mathbf{2}$ and $\mathbf{3}$ as well as the bioassay protocols used for antimicrobial screening technique. All spectra for the spectroscopic characterization including ${ }^{1} \mathrm{H}$ NMR (Figures S1-S12), ${ }^{13}$ C NMR (Figures S13-S24), DEPT 135 (Figures S25-S36), and UV (Figures S37-S48) of the targeted new twelve products were also given in the Supplementary information.

Acknowledgement. The World Academy of Science (TWAS) was gratefully acknowledged by OOA for the sponsorship of this present work under the TWAS Research Grant for Individual Scientists in Basic Sciences Programme (Grant No.: 14-069 RG/CHE/AF/AC_1).

\section{DECLARATION OF INTEREST}

The authors confirm that this article content has no conflict of interest.

\section{REFERENCES AND NOTES} $9,59$.

[1] Kannappan, N.; Reddy, S. R.; Sen, S.; Nagarajan, R.; Dashpute, S. J Appl Chem Res 2009,

[2] Kharb, R.; Kaur, H. Int Res J Pharm 2013, 4, 63.

[3] Sonawane, R.; Tripathi, R. Int Lett Chem Phys Astron 2013, 7, 30.

[4] Chen, Y. J.; Wu, Y. C.; Liu, L.; Li, H. J.; Wang, D. J Org Chem 2006, 71, 6592.

[5] Brouet, J. C.; Gu, S.; Peet, N. P.; Williams, J. D. Synth Commun 2009, 39, 5193.

[6] Sloop, J. C. J Phys Org Chem 2009, 22, 110.

[7] Zhang, X. L.; Wang, Q. Y.; Sheng, S. R.; Wang, Q.; Xiao-Ling, L. Synth Commun 2009, 39, 3293.

[8] Almansour, A.; Arumugam, N.; Kumar, R. S.; Menendez, J. C.; Ghabbour, H. A.; Fun, H. K.; Kumar, R. R. Tetrahedron Lett 2015, 56, 6900.

[9] Pandeya, S. N.; Tyagi, A. Int J Pharm Pharm Sci 2011, 3, 53.

[10] Bingul, M.; Tan, O.; Gardner, C. R.; Sutton, S. K.; Arndt, G. M.; Marshall, G. M.; Cheung, B. B.; Kumar, N.; Black, D. S. Molecules 2016, 21, 916.

[11] Baptiste, N. J.; Kalluyara, B. Der Pharm Chem 2016, 8(5), 167.

[12] Gopinath, V. S.; Pinjari, J.; Dere, R. J.; Verma, A.; Vishwakarma, P.; Shivahare, R.; Moger, M.; Goud, P. S. K.; Ramanathan, V.; Bose, P.; Rao, M. V. S.; Gupta, S.; Puri, S. K.; Launay, D.; Martin, D. Eur J Med Chem 2013, 69, 527.

[13] Wang, X.; Xie, X.; Cai, Y.; Yang, X.; Li, J.; Li, Y.; Chen, W.; He, M. Molecules 2016, 21,340 .

[14] Gupta, S. K.; Mishra, A. Antiinflamm Antiallergy Agents Med Chem 2016, 15, 545.

[15] Chung, P. Y.; Tang, J. C. O.; Cheng, C. H.; Bian, Z. X.; Wong, W. Y.; Lam, K. H.; Chui, C. H. SpringerPlus 2016, 5, 271.

[16] Phopin, K.; Sinthupoom, N.; Treeratanapiboon, L.; Kunwittaya, S.; Prachayasittikul, S.; Ruchirawat, S.; Prachayasittikul, V. EXCLI J 2016, 15144.

[17] Afzal, O.; Kumar, S.; Haider, R. M.; Rahmat, A. M.; Kumar. R., Jaggi, M.; Bawa, S. Eur J Med Chem 2015, 97, 871.

[18] Arafa, R.; Hegazy, G. H.; Piazza, G. A.; Abadi, A. H. Eur J Med Chem 2013, 63, 826. 
[19] Ajani, O. O.; Obafemi, C. A.; Nwinyi, O. C.; Akinpelu, D. A. Bioorg Med Chem 2010, 18,214

[20] Ajani, O. O.; Ajayi, O.; Adekoya, J. A.; Owoeye, T. F.; Durodola, B. M.; Ogunleye, O. M. J. Appl. Sci 2016, 16(3), 77.

[21] Cihan-Üstündağ, G.; Şatana, D.; Özhan, G.; Çapan, G. J Enzym Inhib Med Chem 2016, $31,369$.

[22] Tehrani, K. H. M. E.; Zadeh, M. E.; Mashayekhi, V.; Hashemi, M.; Kobarfard, F.; Gharebaghi, F.; Mohebbi, S. Iran J Pharm Res 2015, 14, 1077.

[23] Kumar, P.; Rai, A.; Singh, M.; Kumar, D.; Sahdev, A. K.; Raj, V. EC Pharm Sci 2016, 2(3), 278.

[24] Verma, G.; Marella, A.; Shaquiquzzaman, M.; Akhtar, M.; Ali, M. R.; Alam, M. M. J Pharm Bioall Sci 2014, 6, 69.

[25] Russell, A. D.; Furr, J. R. J Appl Bacteriol UK 1977, 43, 253.

[26] Ladhani, S.; Garbash, M. Pediatr Drugs 2005, 7(2), 77.

[27] Nair, N.; Biswas, R.; Götz, F.; Biswas, L.; Andrews-Polymenis, H. L. Infect Immun 2014, 82(6), 2162. 